\title{
BUDOWA I PRZEBUDOWA RATUSZA W MIASTACH KRÓLESTWA POLSKIEGO DO KOŃCA XVIII WIEKU
}

Artykuł niniejszy jest próbą syntetycznego ujęcia problemu podnoszonego w literaturze w kontekście poszczególnych regionów i obiektów. Zakres terytorialny jest nieco większy niż sprecyzowany w tytule: uwzględniono również zagadnienia związane ze średniowiecznymi ratuszami Śląka, Pomorza Zachodniego i państwa krzyżackiego.

Najpełniej rozwinięte sa badania nad ratuszami ślaskimi ${ }^{1}$, znaczny jest też stan wiedzy $\mathrm{w}$ zakresie ratuszy pomorskich (w kontekście

${ }^{1}$ M. Zlat, Attyka renesansowa na Ślasku, „Biuletyn Historii Sztuki” (dalej: BHS) 17, 1955, s. 48-79; D. Hanulanka, Sklepienia późnogotyckie na Ślasku, „Rozprawy Komisji Historii Sztuki Wrocławskiego Towarzystwa Naukowego" 7, 1971; G. Balińska, Rozwój urzqdzeń handlowych $i$ administracyjnych $w$ blokach śródrynkowych miast ślaskich do konca XV w., „Kwartalnik Architektury i Urbanistyki” (dalej: KAU) 26, 1981, s. 127-156; R. Czerner, Zabudowy rynków. Średniowieczne bloki śródrynkowe wybranych dużych miast Ślaska, Wrocław 2002; M. Bukowski, M. Zlat, Ratusz wrocławski, Wrocław 1958; M. Zlat, Ratusz wrocławski, Wrocław-Warszawa-Kraków 1976; O. Czerner, Rynek wrocławski, Wrocław-Warszawa-Kraków 1976, s. 138; R. Czerner, C. Lasota, Etapy budowy średniowiecznego ratusza w świetle wyników badań z 1997 r., w: Wrocławski Rynek. Materiaty konferencji naukowej zorganizowanej przez Muzeum Historyczne we Wrocławiu 22-24 pazdziernika 1998 r., red. W. Smolak, Wrocław 1999, s. 14-17; ciż, Blok ratuszowy w Świdnicy do połowy XVI w., Wrocław 1997; ciż, Ratusz i urzqdzenia handlowe na rynku w Głogowie, Wrocław 1994; R. Czerner, Ratusz w Brzegu, Wrocław 1994; J. Trzynadlowski, Stary ratusz we Wroctawiu, Wrocław 2012; M. Chorowska, C. Lasota, Zabudowa rynku świdnickiego do połowy XVI wieku, w: Średniowieczny Ślask i Czechy. Centrum średniowiecznego miasta. Wrocław a Europa Środkowa, „Wratislavia Antiqua” 2, 2000, s. 349-367; Z. Radacki, Ratusz w Głogowie, w: Ze studiów nad średniowiecznym Głogowem i Krosnem, „Prace Lubuskiego Towarzystwa Naukowego. Komisja Historii” 7, 1970, z. 3, s. 119-128; W. Brzezowski, Ratusz Legnicki, „Szkice Legnickie” 10, 1981, s. 52-76; R. Czerner, J. Kościuk, Późnogotyckie elewacje ratusza w Środzie Ślaskiej, „Prace Naukowe Instytutu Historii Architektury, Sztuki i Techniki. Studia i Materiały” (dalej: PN SM) 11, 
basenu Morza Bałtyckiego) ${ }^{2}$, w tym zwłaszcza Gdańska, Torunia, Chełmna i Elblaga, zarówno w dobie krzyżackiej, jak Prus Królewskich; na uwagę zasługuja tu studia nad kompozycją i symbolika architektury i jej wystrojów ${ }^{4}$. Mniej zaawansowane są prace dotyczące ratuszy

Wrocław 1989, s. 39-53; ciż, Program dekoracji architektoniczno-malarskiej ratusza $w$ Środzie Ślaskiej. Badania. Projekt rekonstrukcji, KAU 44, 1999, z. 3, s. 141-149; G. Balińska, Średniowieczny blok rynkowy w Nysie, PN SM 13, Wrocław 1980, s. 3-8; M. Zlat, Lwówek, Wrocław 1961; J. Eysymontt, Ratusz w Lwówku, Wrocław 1981; T. Broniewski, Renesansowy ratusz w Lubaniu Ślaskim, „Teka Konserwatorska” 3, 1956.

${ }^{2}$ Ratusz w miastach pótnocnej Europy. Materiały z sesji „Ratusz w miastach nadbattyckich", Gdańsk 23-25 XI 1993, red. S. Latour, Gdańsk 1997 (tamże m.in. M. Goliński, Hala kupiecka - sukiennice - ratusz, s. 49-51); J. Szczepański, Ratusze polskiego pobrzeża Battyku, Gdańsk 1996.

${ }^{3}$ A. Zbierski, Poczatki Głównego (Prawego) Miasta w Gdańsku, KHKM 23, 1975, nr 1, s. 55-65; L. Krzyżanowski, Niderlandyzm w Gdańsku, w: Sztuka pobrzeża Battyku, Warszawa 1978; T. Domagała, Ratusz Gtównego Miasta w Gdańsku, Warszawa 1980; Z. Maciakowska, Ratusz głównomiejski w Gdańsku - analiza źródet, w: Ratusz $w$ miastach pótnocnej Europy..., s. 105-109; J. Habela, Ratusz staromiejski w Gdańsku, Wrocław-Warszawa-Kraków 1975; E. Gąsiorowski, Ratusz staromiejski w Toruniu, Toruń 2004; tenże, Rynek i ratusz chetmiński, KAU 10, 1965, z. 1, s. 3-28; A. Semrau, Der Markt der Alt-Stadt Elbing im 14. Jahrhundert, „Mitteilungen des Coppernicus-Vereins für Wissenschaft und Kunst zu Thorn” 30, 1922; R. Czaja, T. Nawrolski, Tworzenie miejskiego zespołu osadniczego, w: Historia Elblaga, red. S. Gierszewski, A. Groth, t. 1: Do 1466 r., Gdańsk 1993, s. 72-78; W. Rynkiewicz-Domino, Budownictwo, architektura i kultura artystyczna, w: Historia Elblaga, t. 2, cz. 1: 1466-1626, Gdańsk 1996, s. 238-241 i passim; T. Nawrolski, Średniowieczny plac rynkowy Starego Miasta $w$ Elblagu. Próba analizy przestrzenno-funkcjonalnej, KHKM 40, 1992, nr 3, s. 365-376; tenże, Ratusz odnaleziony, „Spotkania z Zabytkami” 1994, wrzesień, s. 7 i n. [dot. Elblaga]; G. Nawrolska, Problemy badań zespołów miejskich na przykładzie Elblaga, w: 750 lat praw miejskich Elblaga. Księga pamiatkowa. Zbiór artykułów, red. A. Groth, Gdańsk 1996, s. 99-117; taż, Stan badań archeologicznych Starego Miasta $w$ Elblagu, w: Stare Miasto $w$ Elblagu - wyzwanie historii. Materiaty $z$ konferencji naukowej poświęconej pamięci Tadeusza Nawrolskiego, red. G. Nawrolska, J. Mandecki, Elbląg-Gdańsk 1997, s. 21-34.

${ }^{4}$ W. Tomkiewicz, „Alegoria handlu gdańskiego” Izaaka Van dem Blocke, BHS 16, 1954, s. 404-419; J. Stankiewicz, Kilka uwag do artykułu „Alegoria handlu gdańskiego”, BHS 17, 1955, s. 267 i n.; H. Sikorska, Apoteoza łaczności Gdańska z Polska, BHS 30, 1968, s. 228 i n.; E. Iwanoyko, Gdański okres Hansa Vredemana de Vries (studium na temat cyklu malarskiego z ratusza $w$ Gdańsku), Poznań 1963; tenże, Apoteoza Gdańska. Program ideowy malowidet stropu Wielkiej Sali Rady w Gdańskim Ratuszu Gtównego Miasta, Gdańsk 1976; tenże, Interpretacja niektórych elementów wystroju Wielkiej Sali Rady w ratuszu gdańskim, „Gdańskie Studia Muzealne” 2, 1978, s. 9-24; T. Domagała, Wnętrza reprezentacyjnego piętra Ratusza Gtównego Miasta na podstawie inwentarza z końca XVII wieku, „Gdańskie Studia Muzealne” 2, 1978, s. 25-47; T. Zarębska, Przebudowa Gdańska w jego złotym wieku, Warszawa 1998; T. Grzybkowska, Między sztuka a polityka. Sala Czerwona Ratusza Gtównego 
w Wielkopolsce (poza Poznaniem) ${ }^{5}$ i w Małopolsce (wraz z ziemiami ruskimi Korony) ${ }^{6}$. Odrębnym problemem jest rola ratusza w programie i kompozycji miasta nowożytnego, w tym zwłaszcza Zamościa ${ }^{7}$. Ratuszy miast z XVII a zwłaszcza XVIII w. dotyczą pośrednio studia nad urbanistyká ówczesnych miast prywatnych ${ }^{8}$.

Architektura ratuszy - zróżnicowana zarówno chronologicznie, jak topograficznie - może być analizowana według różnych kryteriów. Dla celów niniejszego referatu przyjąłem następujące:

- sytuacja ratusza w zespole urbanistycznym;

- przekształcenia architektoniczne a program i symbolika architektury oraz zmieniające się orientacje artystyczne;

- przekształcenia wystroju i jego symbolika w kontekście tychże orientacji.

1. Sytuacja w zespole urbanistycznym. Powstawanie ratuszy na ziemiach polskich (piastowskich, także krzyżackich) było w oczywisty sposób uwarunkowane wcześniejszą lokacją miasta na prawie niemieckim, przy czym konkretna formuła tego prawa raczej nie miała bezpośredniego przełożenia na formę i sytuację ratusza. Murowany ratusz

Miasta w Gdańsku, Warszawa 2003; W. Rynkiewicz-Domino, Dzieła rodziny Van den Blocków w Elblagu, w: 750 lat praw miejskich Elblaga, s. 141-150.

${ }^{5}$ J. Skuratowicz, Ratusz poznański, Poznań 2003.

${ }^{6} \mathrm{~W}$. Komorowski, Średniowieczne ratusze $w$ Małopolsce $i$ na ziemiach ruskich Korony, w: Civitas et villa. Miasto $i$ wieś w średniowiecznej Europie Środkowej, red. C. Buśko, Wrocław 2002, s. 241-248; tenże, Krakowski ratusz w średniowieczu i Dwór Artusa w Krakowie, „Rocznik Krakowski” 64, 1988, s. 7-33; tenże, Średniowieczny ratusz miasta Kleparza, w: Lapides viventes. Zaginiony Kraków wieków średnich. Ksiega dedykowana Profesor Klementynie Żurowskiej, Kraków 2005, s. 171-182; S. Walczy, S. Załuski, Ratusz $w$ Bieczu $w$ świetle ksiag miejskich $i$ inwentaryzacji architektonicznej, „Studia Historyczne” 1963, s. 170-274; T. Ślawski, Ratusz królewskiego miasta Biecza, siedziba władz samorzadowych na przestrzeni dziejów, Biecz 2000; P. Łopatkiewicz, Chronologia krośnieńskich budowli ratuszowych. Uwagi w kontekście dotychczasowych badań, zachowanych źródet pisanych oraz archeologicznych odkryć na Rynku w Krośnie, „Rzeszowska Teka Konserwatorska” 3-4, 2002, s. 65-81; A. Muzyczuk, M. Bicz-Suknarowska, Odkrycie dwóch obiektów architektury monumentalnej na Rynku w Krośnie, „Rzeszowska Teka Konserwatorska” 3-4, 2002, s. $39-63$.

${ }^{7}$ T. Zarębska, Zamość - miasto idealne i jego realizacja, w: Zamość - miasto idealne. $Z$ dziejów rozwoju przestrzennego i architektury, red. J. Kowalczyk, Lublin 1980, s. 7-77; F. Kotula, Głowów, renesansowe miasteczko, BHS 16, 1954, s. 3-10; S. Herbst, Uwagi nad renesansowym rozplanowaniem Gtowowa, BHS 16, 1954, s. 11-14.

${ }^{8}$ T.F. Szafer, Ze studiów nad planowaniem miast $w$ Polsce XVIII i pocz. XIX w., w: Studia z historii budowy miast, Warszawa 1955, s. 49-81; W. Trzebiński, Działalność urbanistyczna szlachty i magnatów w Polsce XVIII wieku, Warszawa 1962. 
z reguły pojawiał się później niż budynki handlowe ${ }^{9}$ Najogólniej rzecz ujmując - można sytuację tę odnieść do relacji: ratusz-rynek (względnie wnętrze grajace rolę rynku).

1.1. Nieliczną grupę stanowią ratusze położone w pierzei rynku, lub w pełniącej jego funkcję szerokiej ulicy, sporadycznie od owego centrum oddalone. Położenie ratusza w pierzei rynkowej (ulicznej) może wynikać z różnych przesłanek. Wydaje się, że o takiej sytuacji decydowała niekiedy tradycja domu wójta lub rajcy, w którym to domu we wczesnej fazie organizacji władz samorządowych sprawowano czasem czynności urzędowe. Jak to już przed niemal stu laty ustalił Artur Semrau - w państwie krzyżackim siedziba wójta (lub reprezentującego go sołtysa), zlokalizowana poza blokiem śródrynkowym, w pierzei, była pierwszym etapem ewolucji siedziby niewykształconych jeszcze władz miejskich, sprzed wykupów wójtostw ${ }^{10}$; podobne konstatacje dotyczą też innych regionów. Wydaje się, że niekiedy dom rajcy, w którym odbywały się posiedzenia, mógł być nazywany ratuszem. Stan taki zapewne długo utrzymywał się w Nowym Sączu, gdzie dopiero w 1448 r. budynek ratusza, stojący niedaleko kolegiaty, przekazany został kolegiackiej kapitule, może w wyniku zbudowania ratusza w obrębie rynku ${ }^{11}$.

Brak ratusza bywał zjawiskiem typowym w słabiej rozwiniętych miastach (a więc m.in. w wielu miastach małopolskich). Taka sytuacja długo trwała np. w Bieczu, gdzie w 1398 r. rajcy zrezygnowali z użytkowania domu, który zwrócili posiadaczowi ${ }^{12}$, i gdzie jeszcze w 1 . tercji XVI w. sądy sprawowano w gospodzie, za co mieszczan napominał w 1531 r. Zygmunt Stary ${ }^{13}$.

Sytuacja ratusza w pierzei ulicy pełniącej funkcję rynku jest charakterystyczna dla Głównego Miasta w Gdańsku, przy czym - jak przypuszcza Teresa Zarębska - dopiero przekształcanie wschodniego odcinka ulicy Długiej w Długi Targ (od 1370 r.?) zapewniło ratuszowi eksponowaną sytuację jako zamknięcia Targu od zachodu ${ }^{14}$. W „,bezrynkowym" układzie urbanistycznym Elblaga, wykształconym zapewne nie w wyniku lokacji z 1237 r., lecz dopiero po pożarze z roku 1288, mianem

\footnotetext{
${ }^{9}$ R. Czerner, Zabudowy rynków..., s. 47.

${ }^{10}$ E. Gasiorowski, Ratusz staromiejski..., s. 37.

${ }^{11}$ Z. Beiersdorf, B. Krasnowolski, Sztuka gotycka, w: Dzieje miasta Nowego Sacza, t. 1, red. F. Kiryk, Warszawa-Kraków 1992, s. 220.

${ }^{12}$ Najstarsza księa sqdowa miasta Biecza, wyd. B. Ulanowski, Kraków 1896, nr 27.

${ }^{13}$ F. Bujak, Materiaty do historii miasta Biecza 1361-1632, Kraków 1914, s. 60, nr 178.

${ }^{14}$ T. Zarębska, Przebudowa Gdańska..., s. 24 i n.
} 
„starego rynku” określano główna oś uliczna; sytuacja ratusza, dobudowanego zapewne na poczatku XIV w. do nieco starszej budowli targowej (sukiennic?), powiązana została z kształtowaniem placu prostopadłego do owej osi i wypełnianego sukcesywnie przez zabudowę użyteczności publicznej ${ }^{15}$. W bezrynkowym, trzynastowiecznym układzie urbanistycznym Pyrzyc ratusz wpisany został między dwie równoległe ulice, z których jedna odgrywała rolę rynku.

W prywatnych miastach nowożytnych, których układy urbanistyczne podporządkowywano w większym stopniu założeniom estetycznym i symbolice niż względom praktycznym, estetyczne i symboliczne aspekty miała też sytuacja ratusza. Jego położenie w pierzei rynkowej, charakteryzujące manierystyczny Zamość hetmana Jana Zamoyskiego lat 80. XVI stulecia, podyktowane zostało estetyczną funkcją głównego Rynku. Kontynuując - w sensie formalnym - tradycję średniowiecznych założeń szachownicowych, Rynek zamojski jest w zasadzie pozbawiony funkcji, jaka pełnił w średniowiecznych miastach prawa niemieckiego, a w każdym razie funkcja ta jest wielce ograniczona na rzecz reprezentacyjnego wnętrza urbanistycznego, eksponującego m.in. ratusz, którego wydatna bryła przesłoniła skryte na zapleczu urządzenia handlowe ${ }^{16}$. Nieznaczne przesunięcie ratusza $\mathrm{z}$ osi pierzei rynkowej wynikało z zaakcentowania przez ulice krzyżujące się w Rynku głównych osi kompozycyjnych układu urbanistycznego. Według Jerzego Kowalczyka, gdy w plan Zamościa wpiszemy ludzkie ciało, miejsce ratusza odpowiada sercu (podczas gdy pałac - to głowa, a Akademia Zamojska i kolegiata - płuca) ${ }^{17}$.

Schyłek średniowiecza i era nowożytna przynosiły niekiedy akcentowanie estetycznych i symbolicznych walorów kompozycji urbanistycznej poprzez ich adaptacje. Jak wspomniano, problem ten odnośnie do Głównego Miasta w Gdańsku analizowała Teresa Zarębska. W Małopolsce uwage zwraca nietypowa sytuacja ratusza w Wieliczce, salinarnym mieście lokowanym w $1290 \mathrm{r}$. Geneza ratusza nie jest tu znana. $\mathrm{Na}$ aksonometrycznym planie miasta, opracowanym przez Marcina Germana w 1638 r., znajduje się on pośrodku wyniesionej ku górze północnej pierzei rynkowej, występując jednocześnie nieco przed linię zabudowy. Dzięki owemu wyniesieniu i przełamaniu pierzei ratusz

${ }^{15}$ T. Nawrolski, Ratusz odnaleziony..., s. 7 i n.; tenże, Średniowieczny plac rynkowy Starego Miasta $w$ Elblagu. Próba analizy przestrzenno-funkcjonalnej, KHKM 40, 1992, z. 3, s. 365-376; G. Nawrolska, Problemy badań..., s. 101, 104; taż, Stan badań..., s. 21-34, R. Czaja, T. Nawrolski, dz. cyt., s. 72-78.

${ }^{16}$ T. Zarębska, Zamość..., s. 29.

${ }^{17}$ J. Kowalczyk, W kręu kultury dworu Jana Zamoyskiego, Lublin 1980. 
staje się dominantą urbanistyczną rynku, a funkcja taka zdaje się wiązać z estetyką nie średniowieczna, lecz nowożytna. Estetyczne aspekty tej sytuacji podkreśliło utrwalenie jej przez dominantę z lat 80. XVIII w.: pałac „nowobogackiej” rodziny prowadzącej handel sola, który zają miejsce ratusza.

1.2. Bez porównania częstsza jest sytuacja ratusza w obrębie rynku (w miastach o szachownicowej dyspozycji planu lokacyjnego) lub grającej tę samą rolę szerokiej ulicy (w układach urbanistycznych ulicowo-pasmowych). Rynek (szeroka ulica) w programie miasta prawa niemieckiego skupiał wszak funkcje publiczne: wytyczany był jako przestrzeń dla handlu, ale w następnej kolejności (niekiedy również bezpośrednio po lokacji) stawał się także przestrzenią władzy. W zależności od chronologii kształtowania przestrzeni śródrynkowej (względnie bloku śródrynkowego, właściwego m.in. miastom ślaskim oraz kształtowanym pod wpływem Ślaska, np. w Wielkopolsce), miejsce centralne zajmować mogła tu budowla targowa (Kaufhaus; częściej) lub ratusz. Niekiedy ratusz sytuowany był na skraju rynku (po przekątnej w stosunku do kościoła parafialnego?). Najbardziej charakterystycznych przykładów dostarczaja Wrocław i, zapewne wzorujący się na nim w tym zakresie, Kraków. W obu miastach mielibyśmy zatem do czynienia $\mathrm{z}$ wydzieleniem przestrzeni władzy ze skrajnej części rynku, nie zaś z części centralnej, rezerwowanej dla handlu.

Wspomniane przesłanki o charakterze estetycznym i symbolicznym, decydujące o kształtowaniu nowożytnych układów urbanistycznych miast prywatnych, prowadziły do centralnego lub osiowego sytuowania ratusza w obrębie rynku. $\mathrm{Z}$ pierwszym przypadkiem mamy do czynienia m.in. w podkarpackim Głowowie (1570), gdzie kwadratowy w rzucie ratusz zają centralne miejsce na kwadratowym rynku, wyznaczone przez przedłużenia zbiegających się tu ulic - dwóch osi układu ${ }^{18}$. Przypadek drugi reprezentują niektóre założenia późnobarokowe, m.in. Siedlce ${ }^{19}$ (zob. niżej, pkt 2.4).

2. Architektura i jej przekształcenia. Formy architektoniczne, zmieniające się w czasie i przestrzeni, były wynikiem ewolucji programów ratuszy, symbolicznych znaczeń oraz przeobrażeń stylistycznych.

2.1. Faza początkowa (do przełomu XIII i XIV w.). Jak wspomniano, budowa ratusza była wprawdzie konsekwencją lokacji miasta, lecz na ogół nie bezpośrednia, ale odsunięta w czasie. Powstanie

\footnotetext{
${ }^{18}$ F. Kotula, dz. cyt., il. 1; S. Herbst, dz. cyt., s. 11-14.

${ }^{19}$ D. Michalec, O siedleckim ratuszu „Jackiem” zwanym, Siedlce 2009.
} 
rady miejskiej nie musiało automatycznie skutkować wznoszeniem dla niej odrębnego budynku. Z drugiej strony - brak rady nie wykluczał powstania budynku dla pełnienia funkcji urzędowych przez wójta. Najstarsze budowle o przeznaczeniu publicznym były wznoszone $\mathrm{z}$ drewna, a ich wygląd i rola, określane $\mathrm{w}$ oparciu o badania archeologiczne, sa przedmiotem hipotez. I tak np. możemy się jedynie domyślać, że duża budowla konstrukcji szkieletowej, odkryta w Gdańsku pod ulica Długa w sasiedztwie późniejszego ratusza Głównego Miasta, datowana na koniec XIIIw., była związana z obowiązującym tu prawem lubeckim i pełniła funkcję ratusza lub domu kupieckiego (lub obie te funkcje jednocześnie) ${ }^{20}$.

$\mathrm{W}$ wielu wypadkach u podstaw kształtowania programu i form zabudowy śródrynkowej, a więc i pierwszych ratuszy na ziemiach polskich, stały śródrynkowe wieże i hale kupieckie. I tak np. we Wrocławiu, którego nie tylko plan urbanistyczny, lecz również jego wypełnianie przez murowana zabudowę stawały się wzorcem dla wielu miast na ziemiach piastowskich, jeszcze u schyłku XIII w. rajcy zbierali się w kamienicy należącej do jednego z nich, zaś zaczątek przyszłego ratusza, w postaci wznoszonego w latach 1299-1301 consistorium (dwunawowej hali z wieża), służył celom handlowym ${ }^{21}$. Czy wzór wrocławski (prostokątny budynek z wieża) przeszczepiono na rynek Krakowa po lokacji z 1257 r.? Nie tylko wspomniana sytuacja obu budowli - nie w centrum, lecz na skraju rynku, w pobliżu narożnika przeciwległego sytuacji kościoła - jest podobna. W najstarszym założeniu krakowskiego ratusza - budynek wzmiankowany po raz pierwszy w 1316 r. mógł powstać wcześniej, skoro rada wymieniona jest w 1264 r. - wyraźnie wyodrębnia się potężna, kwadratowa wieża (podobna do ślasskich; zob. niżej) i zapewne współczesny jej prostokątny budynek, którego pierwotne podziały wewnętrzne pozostaja nieznane; proporcje nie wykluczaja dyspozycji dwunawowej.

Często - zwłaszcza na Śląsku² - najstarszym elementem zabudowy murowanej (o drewnianej wiemy znacznie mniej), pochodzącym z 2. połowy XIII - przełomu XIII/XIV w., była kwadratowa w rzucie wieża, mieszcząca zazwyczaj więzienie, skarbiec i zbrojownięę, tworząca -

${ }^{20}$ A. Zbierski, dz. cyt., s. 64; zob. też S. Mielczarski, Kiedy Gdańsk uzyskat prawo lubeckie, „Biuletyn Nautologiczny” 2, 1959, nr 12, s. 3-18.

${ }^{21}$ M. Bukowski, M. Zlat, dz. cyt., s. 15, 28 i n.; M. Zlat, Ratusz wroctawski..., s. 36-39; O. Czerner, Rynek wroctawski..., s. 138; R. Czerner, C. Lasota, Etapy budowy..., s. 14 i n.; J. Trzynadlowski, dz. cyt., s. 9.

${ }^{22}$ R. Czerner, Zabudowy rynków...

${ }^{23}$ Tenże, Ratusz $w$ Brzegu..., s. 37. 
obok położonego w sasiedztwie rynku kościoła parafialnego - ideowa i urbanistyczną dominantę miejskiej panoramy, niekiedy sytuowana na przecięciu osi kompozycyjnych bloku śródrynkowego (,w krzyżu”). Od takich prostych w formach, zapewne pozbawionych okazalszego detalu, murowanych z kamienia i cegły wiez, rozpoczęło się według Rafała Czernera i Czesława Lasoty kształtowanie murowanej zabudowy śródrynkowej w miastach śląskich: Wrocławiu, Brzegu, Środzie Ślaskiej, Świdnicy, Głogowie, Głubczycach, Dzierżoniowie, może również w Oławie, Strzegomiu, Ziębicach, Legnicy ${ }^{24}$. Potężne wieże, dominujące nad powiązaną z nimi zabudową śródrynkowa, miały genezę $\mathrm{w}$ beffroi (belfried) z Flandrii i pogranicza flamandzko-francuskiego. W Małopolsce, jak się wydaje, formę wieżową mógł mieć murowany ratusz lokowanego w 1286 r. Sandomierza, zbudowany najpóźniej po zniszczeniu miasta w 1349 r., zaś przy małopolskiej granicy, lecz już na terenie Rusi Halickiej - interpretowana jako dom wójtowski śródrynkowa budowla w Krośnie (pierwotnie w pierzei południowej?), lokowanym na prawie magdeburskim w roku $1342^{25}$. Podobnie - według badań architektonicznych Marka Łukacza - przedstawiałby się zalążek ratusza w Kamieńcu Podolskim ${ }^{26}$.

Charakterystyczna formą „wyjściowa” w kształtowaniu wielu średniowiecznych ratuszy, zwłaszcza na Pomorzu, jest dwunawowa hala ${ }^{27}$. Zlokalizowana na parterze - pełniła funkcje handlowe (mogła też mieścić wagę, zbrojownię, mieszkania służby miejskiej) jako promieniująca z Niderlandów alternatywa dla Kaufhäuser, kształtowanych na Śląsku (ulica rozdzielona rzędami kramów), a w razie potrzeby także funkcje reprezentacyjne: po usunięciu stanowisk kupieckich mogły się tu odbywać przyjęcia, biesiady, nawet inscenizacje teatralne.

W Wielkopolsce do oddziaływań Pomorza nadodrzańskiego odnoszona jest najstarsza forma ratusza poznańskiego, istniejącego zapewne około 1310 r., z dwunawowym rozwiązaniem przyziemia i wysokiego parteru; warto zaznaczyć, że ta tradycja domu kupieckiego - jako najstarszego elementu zagospodarowania przestrzeni śródrynkowej mogła być wcześniejsza, skoro budowę zapowiedział już książę Przemysł I w przywileju lokacyjnym miasta z $1253 \mathrm{r}$. Wieża - mieszcząca

${ }^{24}$ Tamże, s. 41, 126, 128, 130; R. Czerner, C. Lasota, Blok ratuszowy w Świdnicy..., s. 27, 31; ciż, Ratusz i urzqdzenia handlowe na rynku $w$ Głogowie..., s. 14.

${ }^{25}$ A. Muzyczuk, M. Bicz-Suknarowska, dz. cyt., s. 39-63; P. Łopatkiewicz, dz. cyt., s. $65-81$.

${ }^{26}$ W. Komorowski, Średniowieczne ratusze..., s. 243, ryc. 1.

${ }^{27}$ J. Szczepański, dz. cyt., s. 9 i passim; Ratusz w miastach pótnocnej Europy..., passim. 
tu, jak na Śląsku, m.in. skarbiec - może być uważana za oddziaływanie flamandzkich beffrois ${ }^{28}$.

W państwie krzyżackim, gdy siedziba władz miejskich opuszczała dom wójtowski, znajdowała miejsce zrazu w domu kupieckim (Kaufhaus; w Toruniu rajcy zajmowaliby tu pomieszczenie od 1259 r.), by dopiero w następnym etapie pozyskać własna siedzibę ${ }^{29}$.

Oba człony wczesnych ratuszy - wieża i dwunawowa hala - wywodzone są od form właściwych rezydencjom panów feudalnych, a więc form szczególnie prestiżowych, w sposób właściwy dla ideologii mieszczańskiej akcentujących równość stanów mieszczańskiego i rycerskiego. Te aspiracje mieszczaństwa widoczne sa na ziemiach polskich już od początkowych faz wyodrębniania się tego stanu, niemieszczącego się wszak we wczesnośredniowiecznej trójdzielnej strukturze społeczności, definiowanej jako oratores, bellatores i laboratores. Już w 1237 r., gdy wytyczano obszar dla „gości” w Płocku, określono ich jako majacych prawa podobne do rycerzy (rittermeszig man), chociaż rycerzami nie $\mathrm{sa}^{30}$. Symboliczna forma wieży - to akcentowanie zagwarantowanej prawnie miejskiej autonomii poprzez odwołanie się do dominujacego elementu rycerskiego zamku. Znaczenie ideowe mogła też mieć sytuacja, często akcentująca środek rynku, miejsce przecięcia się osi wschód-zachód i północ-południe. Obok wyżej wymienionych względów nie mniej istotne były praktyczne: możliwość obserwacji miasta i jego przedpola, względy obronne. Dwunawowa hala - budowla, można by rzec, wielofunkcyjna, bo w zależności od aktualnej potrzeby mogąca służyć celom reprezentacyjnym, biesiadnym lub handlowym - oparta jest, jak się uważa, na wzorze feudalnego palatium, znanym od wczesnego średniowiecza ${ }^{31}$.

2.2. Późne średniowiecze (XIV-XV/XVI w.) przyniosło istotne przekształcenia form i programów ratuszy. Postępowały one wraz $\mathrm{z}$ bogaceniem się stanu mieszczańskiego, z czym w parze szły coraz większe ambicje estetyczne, a w zamożnych miastach Pomorza z Gdańskiem na czele - także polityczne. Zjawisko to dotyczyło całokształtu architektury mieszczańskiej i miejskiej: prostej, czysto funkcjonalnej, niezdradzajacej niemal żadnych ambicji estetycznych w stadiach

${ }^{28}$ J. Skuratowicz, dz. cyt., s. 9, 12, 14.

${ }^{29}$ E. Gasiorowski, Ratusz staromiejski..., s. 36.

${ }^{30} \mathrm{~K}$. Buczek, O tak zwanym „rittermeszig man” $i$ o gościu $w$ najstarszym spisie prawa polskiego, CPH 12, 1960, s. 1, 141; H. Samsonowicz, Do schytku XV wieku, w: M. Bogucka, H. Samsonowicz, Dzieje miast i mieszczaństwa $w$ Polsce przedrozbiorowej, Wrocław 1986, s. 48-49.

${ }^{31}$ R. Czerner, Ratusz w Brzegu..., s. 90. 
początkowych, po okazała, często oscylująca ku formom pałacowym. Owo przechodzenie od form ściśle użytkowych do wyrafinowanych najwcześniej obserwować można na ziemiach Zakonu Krzyżackiego: dbałość o staranne opracowanie detalu widoczna jest już np. w najstarszej fazie ratusza w Chełmnie (XIII/XIV w.), w postaci profilowanych elementów z formowanej cegły (o wattku wendyjskim), znajdujacych odpowiedniki formalne $\mathrm{w}$ architekturze kościoła farnego ${ }^{32}$, przy czym staranność $\mathrm{w}$ opracowaniu detalu odpowiada tu perfekcyjnej kompozycji urbanistycznej i miejscu ratusza w jej centrum, a więc walorom odbieranym już wówczas w kategoriach piękna. Podobne ambicje w perfekcyjnym kształtowaniu detalu nieco później pojawiają się w architekturze śląskiej, jeszcze później - bo w zasadzie dopiero w dobie Kazimierza Wielkiego - w Krakowie.

W ratuszach Pomorza - zarówno Zachodniego, jak Wschodniego (państwa krzyżackiego) - charakterystycznym elementem była nadal dwunawowa hala, przejęta $\mathrm{z}$ feudalnych zamków, zaś $\mathrm{w}$ fasadzie przy krótszym boku - podcienia. Przykładami sa przebudowy ratuszy w Kamieniu Pomorskim z połowy XIV w., Stargardzie z końca XIV w., Braniewie z około 1400 r., Elblagu z początku XV w., w Chojnie i Szczecinie z połowy XV w., w Pasłęku z 2. połowy XV w. ${ }^{33}$ Wczesnym przykładem symetrycznego rozwiązania jest ratusz w Malborku, zbudowany zapewne w okresie 1365-1380, z podcieniową fasadą stanowiąca bok dłuższy ${ }^{34}$.

Już na lata 1328-1333 przypadła pierwsza faza rozbudowy ratusza wrocławskiego (może w związku z ówczesnym wykupem przez miasto wójtostwa), a kolejne fazy - to lata 1343-1357, 2. połowa XIV stulecia i wiek $\mathrm{XV}^{35}$. Od 2. połowy - końca XIV w. do schyłku gotyku odnotować należy postępujący etapowo rozwój architektoniczny ratuszy i bloków śródrynkowych, doskonale widoczny na Śląsku. Często podwyższane były wieże, budynki osiagały piętrowe gabaryty, różnicowany był program. W ratuszach o szczególnie rozbudowanych programach pojawiały się

${ }^{32}$ E. Gąsiorowski, Rynek i ratusz..., s. 13, ryc. 11; T. Chrzanowski, M. Kornecki, Chetmno, Wrocław-Warszawa-Kraków 1991, s. 55.

${ }^{33}$ K. Kalita-Skwirzyńska, Stargard Szczeciński, Wrocław 1983; taż, Ratusz $w$ Chojnie, „Przegląd Zachodnio-Pomorski” 1987, z. 3, s. 91-108; G. Nawrolska, Problemy badań..., s. 111; K. Kroman, Ratusz w Kamieniu Pomorskim, „Rocznik Kamieński” 2, 1967, s. 43-60; K. Kalita-Skwirzyńska, A. Włodarek, Szczecin. Ratusz, hasło w: Architektura gotycka $w$ Polsce. Katalog zabytków, red. A. Włodarek, Warszawa 1995, s. 222; A. Rzempołuch, A. Włodarek, Pasłęk. Ratusz, hasło w: tamże, s. 182.

${ }^{34}$ H. Dziurla, Malbork. Ratusz, hasło w: Architektura gotycka..., s. 155-156.

${ }^{35}$ J. Trzynadlewski, dz. cyt., s. 9-10. 
kaplice (m.in. w Świdnicy zapewne już w XIV w.). Rozbudowy niekiedy oznaczały adaptację przyległych kramów; w niektórych wypadkach (Świdnica) funkcjonowały one nadal w przyziemiu ratusza, co z kolei wywierało wpływ na programy ratuszy późnogotyckich i nowożytnych, z dyspozycja parteru odpowiadającą rozplanowaniu kramów, zarówno we wspomnianej wersji dwunawowej hali, jak w charakterystycznej dla wzorów promieniujacych ze Ślaska sieni dzielącej dwa pasma kramów. Tego rodzaju rozwiązanie w Małopolsce chyba wcześnie uzyskał ratusz krakowskiego Kazimierza, skoro rzut parteru - zachowany do dzisiaj w ramach renesansowej przebudowy - zdaje się wykazywać bezpośredni związek z dwoma rzędami kramów sukienniczych, dobudowanych doń od południa w oparciu o przywilej Władysława Jagiełły z 1387 r. ${ }^{36}$ Podobna relacja między ratuszem a sukiennicami zachodziła w Bochni, gdzie prostokątny rynek wytyczono zapewne w wyniku Kazimierzowskiej regulacji.

Zagospodarowywanie bloku śródrynkowego z ratuszem i kramami, zazwyczaj postępujące ewolucyjnie w ciagu wieków, niekiedy realizowano według jednolitej koncepcji, likwidując elementy wcześniejsze. Rozwiąanie takie już około 1274 r. miało miejsce na rynku Starego Miasta w Toruniu. Uznane zapewne za zbyt skromne, zostało zastapione znacznie okazalszym, przybierajacym formy gotyckiego pałacu, kształtowanym od roku 1393 (w pierwszej fazie z udziałem miejskiego budowniczego Andrisa), jako kolejne, jednolicie skomponowane, czteroskrzydłowe, zgrupowane wokół podpiwniczonego dziedzińca założenie, wypełniające centralną część rynku, obejmujące rozbudowany program ratusza (piętro) i kramów (przyziemie). Elementem prestiżowym pozostawała wieża (jedyna część budowli przejęta ze starszego założenia). Całość przypomina wzory flamandzkie (wieża jako beffroi), przy jednoczesnym nawiązaniu do Lubeki (ściana parawanowa). Modularne ukształtowanie rzutu i elewacji (rozmierzenie według powtarzalnego, wyliczalnego w prętach modułu) zawiera charakterystyczne dla miast prawa niemieckiego (a także dla kultury humanistycznej) przekonanie o pięknie wynikającym z proporcji. Wybitne walory ceglanej architektury Torunia doceniano już w średniowieczu, o czym świadczą zarówno zachwyty Jana Długosza ${ }^{37}$, jak fakt powierzenia w 1454 r. toruńskiemu mistrzowi Janowi przebudowy krakowskiego ratusza, w wyniku której ukształtowana została

${ }^{36}$ Kodeks dyplomatyczny miasta Krakowa, t. 1, wyd. F. Piekosiński, Kraków 1879, nr 244 .

${ }^{37}$ E. Gasiorowski, Ratusz staromiejski... 
jego znana z ikonografii bryła, z wysokimi dachami, wspartymi na sterczynowych szczytach ${ }^{38}$.

Teresa Zarębska wiąże okazałe formy ratusza Głównego Miasta w Gdańsku, wprowadzane od rozbudowy zrealizowanej w latach 1379-1382 przez budowniczego Henryka Ungeradina, ze wspomnianym utworzeniem Długiego Targu. Ostateczne ukształtowanie zamierzonej już wówczas wieży, przypadające na 1465 r., określa jako „deklarację niepodległości”, widząc je jako część kolejnych przekształceń urbanistycznych, prowadzących do „monumentalizacji centrum”. Niderlandzkim odniesieniem stała się nie tylko forma wieży w typie beffroi, lecz także nieco późniejsza attyka wieńcząca elewację zachodnią i podwyższająca ją optycznie, jak analogiczny motyw domu Oosterlingów w Brugii ${ }^{39}$.

Wieże ratuszy Torunia i Gdańska oraz niderlandzkie formy beffroi nie były jednak na Pomorzu zjawiskiem typowym. Dominowały rozwiązania bezwieżowe, najwyżej $\mathrm{z}$ niewysoka wieżyczka na sygnaturkę, z dekoracją architektoniczną koncentrująca się w wysokim szczycie. Wczesnym przykładem okazałego rozwiązania jest ratusz w Brodnicy (XIV/XV w.), ze szczytem zaakcentowanym na osi ośmioboczną wieżyczka, co znajduje lokalną analogię w szczycie toruńskiego kościoła franciszkanów ${ }^{40}$. Ratusz Nowego Miasta w Toruniu (zburzony w 1818 r., znany z ikonografii), zbudowany w 1303 lub dopiero w 1347 r., z obejmująca m.in. sukiennice hala targową na parterze ${ }^{41}$, wyróżniał się artykulacją bocznych elewacji, gdzie alternowały strzeliste wnęki i odpowiadające im okna ${ }^{42}$. W bezwieżowych ratuszach Pomorza Zachodniego pojawiały się ściany attykowe; przykładem z połowy $\mathrm{XV}$ w. jest ratusz szczeciński, zapewne nawiązujący do Stralsundu.

Funkcje reprezentacyjne, podkreślające prestiż i autonomię miasta, wymagały kształtowania wnętrz o odpowiednim charakterze. Nadawały się na nie owe dwunawowe hale. Na Pomorzu funkcje tego rodzaju - wykraczające poza program związany ściśle z urzędowaniem władz miejskich - przenoszone bywały $\mathrm{z}$ hali w przyziemiu ratusza do specjalnych budowli, zwanych Dworami Artusa. Już sama nazwa wyrażała wysokie ambicje stanu mieszczańskiego, przejmującego na swój użytek wczesnośredniowieczne legendy o królu Arturze i rycerzach Okragłego Stołu. Początek dało Główne Miasto w Gdańsku, gdzie w swej pierwotnej - nieznanej - formie curia regis Artus powstała zapewne

\footnotetext{
${ }^{38}$ W. Komorowski, Krakowski ratusz..., s. 18-19, il. 7, 8.

${ }^{39}$ T. Zarębska, Przebudowa Gdańska..., s. 24, 28, 31-33.

${ }^{40}$ T. Mroczko, Architektura gotyku na Ziemi Chetmińskiej, Warszawa 1980, s. 312.

${ }^{41}$ J. Szczepański, dz. cyt., s. 77.

${ }^{42}$ T. Mroczko, dz. cyt., 281.
} 
w latach 1348-1350, w kolejnych zaś formach w 1379 r.(? ${ }^{43}$ i po pożarze z 1479 r. Wzory te mogły sięgać poza Pomorze. Zapewne rację ma Waldemar Komorowski, domyślając się uzupełnienia programu krakowskiego ratusza (wykazującego - poza potężna wieżą - pewien „niedorozwój” w zestawieniu z programami ratuszy w miastach o podobnym znaczeniu) o część recepcyjna, która miałby mieścić tajemniczy budynek we wschodniej pierzei Rynku, odpowiadający sytuacji późniejszej kamienicy Montelupich, z dwunawową halą w przyziemiu.

Problem datowania faz budowy krakowskiego ratusza ${ }^{44}$ wciąż pozostaje niewyjaśniony. Czy domniemana nadbudowa piętra w 2. połowie (końcu?) XIV w. związana była z gruntownym przekształceniem wieży, wraz z powstaniem jej okazałego architektonicznego wystroju? Pytanie to pozostaje bez odpowiedzi wobec rozbieżności w datowaniu owego wystroju (dopiero 1. połowa XV w.?), integralnie związanego $\mathrm{z}$ architektura.

Wzory małopolskie (a pośrednio ślaskie) oddziaływały na proces formowania układów urbanistycznych i zabudowy miejskiej na Rusi Halickiej. W wyniku kilku faz budowlanych kształtowano - w obrębie bloku śródrynkowego - ratusz we Lwowie, wzmiankowany od 1382 r. (starsze akta spaliły się). Zakrojona na szeroką skalę rozbudowa (we wmurowaniu kamienia węgielnego wziął udział Jan Olbracht) przypadła na lata 1489-1504; w jej wyniku powstała okazała, piętrowa budowla $\mathrm{z}$ wieża, określana później jako palatium praetorii ${ }^{45}$.

Ratusze w głównych miastach Ślaska zyskiwały reprezentacyjny charakter późnogotyckich pałaców miejskich w wyniku kolejnych przebudów ${ }^{46}$, prowadzonych przez wybitnych budowniczych i kamieniarzy, co świadczy o wysokim poziomie mieszczańskiego mecenatu. Na czoło wysuwa się rozbudowa ratusza we Wrocławiu, realizowana w kilku etapach w latach 1470-1510, wprowadzająca wykusze, wysokie, dekoracyjnie kształtowane szczyty i okazały wystrój plastyczny (zob. niżej) ${ }^{47}$. Wybitnym dziełem architektury schyłkowego ślaskiego gotyku jest rozbudowa ratusza we Lwówku Ślaskim ${ }^{48}$, dokonana w latach 1522-1524 zapewne przez Wendela Roskopfa, architekta czynnego w Zgorzelcu,

${ }^{43}$ Gdańsk średniowieczny $w$ świetle najnowszych badań archeologicznych $i$ historycznych, red. H. Paner, Gdańsk 1998.

${ }^{44}$ W. Komorowski, Krakowski ratusz..., s. 7-33.

${ }^{45}$ F. Jaworski, Ratusz lwowski, Lwów 1907 (Biblioteka Lwowska, 1), s. 14-18;

L. Podhorecki, Dzieje Lwowa, Warszawa 1993, s. 51.

${ }^{46}$ J. Pilch, Ratusze ślaskie woj. wrocławskiego, Wrocław 1965.

${ }^{47}$ J. Trzynadlowski, dz. cyt., s. 10.

${ }^{48}$ D. Hanulanka, dz. cyt., s. 95, 117-119. 
ucznia praskiego mistrza Benedykta Rejta, którego czołowe dzieło reprezentacyjna Sala Władysławowska zamku królewskiego na Hradczanach - zostało tu powtórzone w pomniejszonej skali i z nieco sprowincjonalizowanym detalem wijących się wężowo żeber sklepiennych. Nawiązanie do świetnego królewskiego wzoru traktować należy z jednej strony jako zaakcentowanie związku miasta i Ślaska z Korona Czech, z drugiej - jako wyraz ambicji bogatego mieszczaństwa. Jednocześnie we lwóweckim ratuszu odzwierciedlenie znalazł promieniujący z Italii renesans; anonimowy włoski kamieniarz był zapewne autorem monumentalnych obramień okiennych, notabene stanowiących również nawiazanie do praskiej Sali Władysławowskiej. Podobne cechy - zwiazane ze stylem właściwym dla Roskopfa - prezentował ratusz w Bolesławcu (w znacznym stopniu przebudowany). Za epigonalne zjawisko w kształtowaniu późnogotyckich wnętrz śląskich ratuszy należy uznać prace budowniczego Hansa Lindnera w Lubaniu (około 1541) i w Głogowie; w tym ostatnim ratuszu - dzisiaj niezachowanym - pojawiło się sklepienie kryształowe, właściwe dla oddziaływań Saksonii ${ }^{49}$.

W formach architektonicznych coraz liczniejsze były nawiązania do symboliki przejętej $\mathrm{z}$ siedzib i obyczajów rycerstwa ${ }^{50}$. W późnym średniowieczu to już nie tylko wieże (ich stałe podwyższanie można uznać za pewnego rodzaju rywalizację z wieżami kościołów), lecz także blankowania wieńczace mury, machikuły, wykusze (w najbogatszej formie wprowadzone na przełomie XV i XVI w. w ratuszu wrocławskim).

2.3. U progu ery nowożytnej (XVI-XVI/XVII w.) odnotować należy liczne rozbudowy ratuszy, z gruntownym przekształcaniem detali architektonicznych i brył, które zwłaszcza w bogatych miastach Prus Królewskich i Śląska stawały się istotnym elementem kształtowania miejskich panoram. Zróżnicowanie stylowe można, z pewnym uproszczeniem, odnieść do oddziaływania dwóch biegunów: „zitalianizowanej” kultury artystycznej promieniującej z Krakowa i „niderlandyzmu" płynącego z Gdańska ${ }^{51}$, przy czym podział ten nie jest ani ostry, ani jedyny. $Z$ jednej bowiem strony w Krakowie obecne były elementy niderlandzkie (ale tylko w wystroju; zob. niżej), z drugiej - w Gdańsku obok licznych przybyszów z Niderlandów działali też Włosi, z których jeden miał decydujaccy wpływ na ukształtowane w 1552 r. ówczesnej (niezachowanej) fasady gdańskiego Dworu Artusa. Nie wszystkie wpływy włoskie płynęły przez Kraków, zasadniczo zdominowany przez

\footnotetext{
${ }^{49}$ Tamże, s. 120, 126.

${ }^{50}$ Por. R. Czerner, Ratusz w Brzegu..., s. 90.

${ }^{51}$ L. Krzyżanowski, dz. cyt.
} 
Florentczyków; Komaskowie przeważali na Śląsku i we Lwowie, a jeden z najznakomitszych spośród nich, Giovanni Battista Quadro z Lugano, kształtował przebudowywany w latach 1550-1560 ratusz w Poznaniu.

Dzięki wspomnianej przebudowie i wspomnianemu budowniczemu jest to najefektowniejszy na ziemiach polskich ratusz renesansowy ${ }^{52}$. Północnowłoski architekt nawiązał do wzorów z traktatu Sebastiana Serlia $^{53}$. Nawiązania te sa wyjątkowo wczesne, bo zaledwie o 3 lata późniejsze od publikacji ostatniej księgi traktatu, współczesne ostatnim latom życia Serlia (zmarł w 1554 r.), a kilkadziesiąt lat wcześniejsze od całościowego wydania dzieł (w Amsterdamie w 1606 r.), które serliańskie wzory szeroko spopularyzowało. Zbieżności widzimy zarówno $\mathrm{w}$ ukształtowaniu filarowo-arkadowych galerii w fasadzie, jak i w rozwiązaniu schodów przed fasada i reprezentacyjnej klatki schodowej we wnętrzu, jak, wreszcie, w wielu detalach. Wspomniana galeria, z której odczytywano akty prawne wydawane przez władze miejskie i państwowe - to nawiązanie, poprzez Serlia, do budowli starożytnego Rzymu: portyku Pompejusza (motyw zdwojonych arkad) i Colosseum, co zapewne miało oznaczać „zrównanie” Poznania z Wiecznym Miastem, a poznańskich rajców i mieszczan z Senatus Populusque Romanus. Wewnątrz wręcz kopią rysunku Serlia sa geometryczne podziały (a częściowo też ich ornamentalna dekoracja) na sklepieniu reprezentacyjnej Wielkiej Sieni (Sali Ławy) na parterze oraz niektóre portale.

Na Śląsku przeobrażenia architektury ratuszy w dobie renesansu i manieryzmu miały zróżnicowany charakter. Najwcześniej dotarły do Wrocławia: renesansowy portal we wnętrzu z 1528 r., umieszczenie w 1534 r. na wieży herbu miasta, nadanego 4 lata wcześniej przez cesarza, oraz wprowadzenie „śpiewającego zegara” (1550) $)^{54}$ - to jedne z ostatnich znaczacych inwestycji decydujących o bogactwie pałacu miejskiego. W innych ratuszach śląskich wpływy północnowłoskie

${ }^{52}$ J. Skuratowicz, dz. cyt., s. 19-23; T. Jakimowicz, Sztuka renesansu i manieryzmu w Poznaniu, w: Dzieje Poznania, t. 1, cz. 1, red. J. Topolski, Poznań 1988; taż, Temat historyczny epoki ostatnich Jagiellonów, Poznań-Warszawa 1985; J. Wiesiołowski, Galeria heraldyczna ratusza poznańskiego. Próba identyfikacji osób i określenia czasu powstania przedstawień heraldycznych, „Kronika Miasta Poznania” 1997, nr 3, s. 337 i n.

${ }^{53}$ J. Kowalczyk, Sebastiano Serlio a sztuka polska, Wrocław-Warszawa-Kraków 1973, s. 65, 82-84, 94, 202-203, 253-254; tenże, Inspiracje Serlia i watki antyczne $w$ fasadzie poznańskiego ratusza, BHS 30, 1968, nr 3, s. 401-404; tenże, Fasada ratusza poznańskiego. Recepcja form z traktatu Serlia i antyczny program, „Rocznik Historii Sztuki” 8, 1970, s. 149-160.

${ }^{54}$ J. Trzynadlowski, dz. cyt., s. 10; M. Batycki, R. Sachs, Zegar ratuszowy we Wrocławiu, w: Wroctawski Rynek..., s. 29. 
odzwierciedlały się $\mathrm{w}$ tendencjach do horyzontalnego wieńczenia brył attykami, kształtowanymi odmiennie niż w Małopolsce, wprowadzonymi m.in. w Dzierżoniowie, Głubczycach (attyka zburzona w 1862 r.), Oleśnicy, Paczkowie (zburzona w 1840 r.; zachowana tylko na wieży), Ząbkowicach ${ }^{55}$. Odrębna pozycję zajmuje ratusz w Brzegu. Podjęcie jego gruntownej przebudowy przyśpieszył pożar z 1569 r., lecz ukształtowanie budowli jako reprezentacyjnego pałacu miejskiego rozważano zapewne wcześniej (i to może na wielką skalę), skoro dwa lata przed pożarem zakupiono plany słynnego ratusza w Antwerpii. Lokalne tradycje - wysokie dachy i szczyty - zadecydowały o nadanej bryle formie (około 1570 - około 1577), aczkolwiek prace prowadzili budowniczowie północnowłoscy: czynny tu wcześniej na zamku Jakub Parr z Mediolanu i jego szwagier Bernard Niuron (autor projektu?), którzy w fasadowej loggii ujętej parą ryzalitów nawiązali do serliańskiego wzorca willi Poggio-Reale ${ }^{56}$. „Niderlandyzm” zaznaczył się w manierystycznym hełmie ratusza wrocławskiego.

Dla renesansowych ratuszy małopolskich, skromnych w swych programach i rozmiarach w zestawieniu nie tylko z Pomorzem, lecz i z czołowymi ośrodkami Ślaska i Wielkopolski, charakterystyczne bywały przebudowy zgodne z nową estetyka, promieniująca z Italii przez Kraków: elewacje tynkowane zamiast ceglanych z dekoracją sgraffitowa (a niewątpliwie też malarska), attyki maskujace dachy pogrążone w miejsce dachów wysokich. Klasycznymi przykładami sa tu prowadzone w 3. ćwierci XVI w. przebudowy ratuszy Tarnowa, krakowskiego Kazimierza, Sandomierza i Nowego Sacza oraz budowa ratusza w Krośnie (oba ostatnie niezachowane); w Tarnowie i Sandomierzu pierwotny efekt kolorystyczny i materiałowy został w 2 . połowie XIX w. zakłócony niewłaściwymi restauracjami, eksponującymi - wbrew estetyce włoskiego renesansu - cegłę.

Wydaje się, że sprawą oczywistą dla ówczesnych małopolskich zleceniodawców było powierzanie przebudów ratuszy muratorom z Italii. Włoski charakter architektury wspomnianego ratusza nowosądeckiego ${ }^{57}$ potwierdzają źródła pisane w postaci umów zawieranych przez rajców z budowniczymi. W 1562 r. zadecydowano o budowie ratusza „włoskim sposobem” (,muracione pretorii more italico”), a zadanie to realizować miał według własnego projektu włoski murator imieniem

${ }^{55}$ M. Zlat, Attyka..., s. 48-79.

${ }^{56}$ R. Czerner, Ratusz w Brzegu..., s. 92-103.

${ }^{57}$ Z. Beiersdorf, B. Krasnowolski, Sztuka renesansu i manieryzmu, w: Dzieje miasta Nowego Sqcza, t. 1, s. 495-500, 502-505. 
Lodovico. Zaczęte przezeń prace kończył rok później murator Mateusz z Krakowa (niewykluczone, że tak nazwany został w dokumentach Mateo Gucci, krewny królewskiego budowniczego i rzeźbiarza Santi Gucciego). Włoch - może Giovanni Maria il Mosca zwany Padovanem - był zapewne autorem dokonanej w latach 1558-1561 przebudowy ratusza tarnowskiego z attyką wzorowana na krakowskich Sukiennicach. W Sandomierzu pracować miał przy ratuszu w 1565 r. Joannes Italus. Autorem przebudowy ratusza kazimierskiego był zapewne jeden z licznych włoskich muratorów posiadajacych tutejsze prawo miejskie. Późnym przykładem podobnego rozwiązania jest ratusz w Szydłowcu, zbudowany w latach 1602-1605 przez spolonizowanych włoskich muratorów, Kaspra i Wojciecha Fodygów ${ }^{58}$; symetryczny, zwarty rzut z wieżą i sienią akcentująca oś można uznać za uproszczone nawiązanie do ratusza w Zamościu.

Swego rodzaju nawiązanie do tradycji średniowiecza spotykamy w Bieczu ${ }^{59}$. Tutaj - podobnie jak w Krakowie - stosunkowo niewielki budynek ratusza całkowicie zdominowany został przez wyjątkowo wysoka wieżę, ukształtowana w znanej nam postaci (w miejscu wieży niewiele zapewne starszej), dopiero po pożarze w $1569 \mathrm{r}$. przez przybyłego z Wrocławia muratora Jeremiasza Quaiera. Średniowieczna symbolika wieży, rywalizującej tu z bryłą ukończonego zaledwie kilkadziesiąt lat wcześniej parafialnego kościoła, mogła być „podpowiedziana” przez związanego z Bieczem humanistę Marcina Kromera i zaprzyjaźnionego z nim ks. Tomasza Mateusza Żydka zwanego Płaza, który w toku budowy pisał z zachwytem do Kromera: „nie będzie takiej wieży in Regno" "60. Pozostałe elementy architektonicznego wystroju - niezachowana dzisiaj attyka, nadal istniejąca dekoracja sgraffitowa - nie odbiegają od małopolskich standardów.

Odrębne miejsce zajmuje ratusz w Zamościu ${ }^{61}$, wzmiankowany od 1584 r. (a więc już 3 lata po wytyczeniu planu urbanistycznego miasta), w swej pierwotnej postaci - podobnie jak układ urbanistyczny - dzieło północnowłoskiego architekta Bernarda Morando, realizujące ambicje Jana Zamoyskiego. Ogólne podobieństwo do renesansowych ratuszy małopolskich (prostokątny plan, bryła zwieńczona niezachowaną dziś attyka), jest tu tylko rodzajem architektonicznego języka, umiejętnie operującego stereotypem ratusza, funkcja bowiem - zarówno pod

\footnotetext{
${ }^{58}$ A. Król, Kasper Fodyga, budowniczy chęciński, BHS 12, 1951, s. 89, 107-114.

${ }^{59}$ S. Walczy, S. Załubski, dz. cyt., s. 170-274; T. Ślawski, dz. cyt.

${ }^{60}$ Cyt. za: S. Walczy, S. Załubski, dz. cyt., s. 170.

${ }^{61}$ T. Zarębska, Zamość..., s. 41-42.
} 
względem prawnym, jak ideowym, kompozycyjnym i urbanistycznym - jest w zasadzie odmienna, całkowicie indywidualna. Zamość miał się wszak stać centrum niemal suwerennej ordynacji magnackiej, z własna organizacją wielowyznaniowego życia religijnego (przy oczywistej dominacji Kościoła katolickiego; według pierwotnych zamierzeń kolegiata miałaby się stać katedra), naukowego (Akademia Zamojska) i własna struktura prawna, niezależna od koronnych trybunałów w Piotrkowie i Lublinie, które dla dóbr zamojskich zastapił Trybunał Zamojski (tworzony w latach 1601-1604) z siedzibą właśnie w ratuszu. To tę głównie funkcję akcentowała wysoka wieża na osi fasady, eksponowana nie tylko z wnętrza Rynku, lecz i z wybiegających nań ulic.

Równolegle $\mathrm{z}$ kształtowaniem renesansowych form ratuszy małopolskich przebiegała budowa okazałego ratusza lwowskiego, prowadzona od 1561 r. z udziałem północnowłoskiego budowniczego Gabriela Quadro, ukończona w 1619 r. wzniesieniem górnej, wysokiej, ośmiobocznej części wieży ${ }^{62}$. Znana z ikonografii - zwieńczona attyką - jest zgodna $\mathrm{z}$ formami dominującymi w Małopolsce.

Odmienny świat form prezentuje nowożytna architektura Pomorza, opierana nadal w znacznej mierze na wzorach niderlandzkich, rozwijająca się raczej jako kontynuacja, a nie negacja form średniowiecznych. Wraz z emigrantami z ogarniętych wojnami religijnymi Niderlandów docierały tu wzorniki Cornelisa Florisa, a nieprześcignioną realizacja stawał się budowany/przebudowywany przezeń w latach 1560-1565 ratusz w Antwerpii, wiążący „północne” poczucie formy z italianizującym detalem i ,antyczna” symbolika. Przekształcanie średniowiecznych ratuszy, dokonywane powszechnie w 2 . połowie XVI i na początku XVII stulecia, szło w parze z gruntownymi przekształceniami miejskich panoram; symbolika ratusza jako mieszczańskiego pałacu, a zarazem twierdzy, znajdowała praktyczne odzwierciedlenie w rozbudowie systemów obronnych i budowie miejskich arsenałów.

Do najwcześniejszych dzieł orientacji niderlandzkiej należała fasada ratusza w Elblagu (około 1550-1556) ${ }^{63}$, znana niestety tylko z mało precyzyjnego przekazu ikonograficznego.

Epokę renesansu i manieryzmu w gdańskim ratuszu Głównego Miasta otwiera ukształtowanie trzech nowych skrzydeł (1537-1552), ujmujących wraz $\mathrm{z}$ dawnym prostokatny dziedziniec ${ }^{64}$. Można zapytywać: czy to nawiązanie do dziedzińcowych, pałacowych realizacji

\footnotetext{
${ }^{62}$ F. Jaworski, dz. cyt., s. 21-25.

${ }^{63}$ W. Rynkiewicz-Domino, Budownictwo..., s. 238-240.

${ }^{64}$ T. Zarębska, Przebudowa Gdańska..., s. 39.
} 
włoskich (wówczas już anachronicznych), czy spóźnione nawiązanie do staromiejskiego ratusza w Toruniu? A może jedno i drugie? Średniowieczna tradycję - przy manierystycznym detalu - reprezentuje nadbudowa wieży, wykonana po pożarze w 1561 r. (hełm autorstwa Dirka Danielsa). W pełni nowożytny (oczywiście w sensie niderlandzkim, nie włoskim) charakter miała dopiero ostatnia faza przekształceń (1593-1596): podwyższenie drugiego piętra i wprowadzenie wielkich, reprezentacyjnych okien ${ }^{65}$.

Ratusz Starego Miasta w Gdańsku ${ }^{66}$ - to kolejne wybitne dzieło niderlandzkiego manieryzmu (1587-1594), pozostające w zgodzie ze średniowieczna tradycja, nawiąujace do ratuszy flamandzkich, m.in. do Mechelen, skąd pochodził domniemany autor, Antoni van Obbergen; jego powołanie na stanowisko głównego architekta Gdańska w miejsce Hansa Vredemana de Vries - to zwycięstwo niderlandzkiego architekta praktyka nad niderlandzkim malarzem i architektem wizjonerem. Budowla ta wiąże aż dwie dwunawowe hale, a więc tradycyjna formę odwołująca się do wnętrz pałacowych, przy czym handel został tu całkowicie wyeliminowany przez reprezentacyjność. Bezwieżowa bryłę można uznać za typową cechę dla Pomorza (Gdańsk i Toruń sa wyjątkami).

Nieomal symbolem kontynuacji form tradycyjnych jest rozbudowa staromiejskiego ratusza w Toruniu, dokonana w latach 1602-1605 przez Antoniego van Obbergen, polegająca na nadbudowie drugiego piętra $\mathrm{z}$ całkowitym powtórzeniem zarówno artykułowania elewacji w postaci gotyckich wnęk ostrołukowych, jak i bryły z wysokimi dachami ${ }^{67}$. Utrzymywanie ceglanych elewacji, często łaczonych z kamiennym detalem, to jedna z najsilniej rysujących się cech stylowych tej północnoeuropejskiej architektury. Charakterystyczna była tu dbałość o wysoki poziom architektury i jej wystroju. W symbolice detali architektonicznych podobnie jak na południu Polski - istotna rolę grały niekiedy dekoracyjne krenelaże, nawiązujące wprost, bez posługiwania się attyka, do idei corona muralis. Częściej niż $\mathrm{w}$ innych regionach nowożytne ratusze pobrzeża Bałtyku sytuowano w pierzejach; przykładów dostarczaja Koszalin, Puck, Darłowo ${ }^{68}$.

Równie wymownym przykładem trwałości wzorców średniowiecznych jak przebudowa toruńskiego ratusza sa dokonywane w kilku

\footnotetext{
${ }^{65}$ T. Grzybkowska, dz. cyt., s. 17.

66 J. Habela, dz. cyt., s. 30-81.

${ }^{67}$ E. Gasiorowski, Ratusz staromiejski..., s. 92.

${ }^{68}$ J. Szczepański, dz. cyt., s. 6.
} 
etapach przebudowy gdańskiego Dworu Artusa, gdzie nadal czytelne - a więc $\mathrm{w}$ pełni akceptowane - formy gotyckie uzupełniły elementy manierystyczne w wydaniu zrazu włoskim (faza z 1552 r.), a ostatecznie niderlandzkim (Abraham van den Blocke, 1617 r.) oraz skomplikowany program ikonograficzny (zob. niżej). W podobnym czasie powstał nowy Dwór Artusa w Elblagu (1578; znany z ikonografii), którego szczyt dekorowany był charakterystycznym dla niderlandzkiego manieryzmu ornamentem okuciowym.

Nietypowym przykładem z terenu Pomorza jest ratusz w Chełmnie $^{69}$, przebudowany gruntownie w latach 1567-1572, a więc równolegle z przekształceniami licznych ratuszy małopolskich, jak one zwieńczony attyka kryjąca dachy pograżone. „Pałacowy” program zadecydował o potraktowaniu piętra - z Sala Rady - jako piano nobile. Przypuszcza się, że autor mógł pochodzić znad jeziora $\mathrm{Como}^{70}$, a jego dziełami byłyby attyka kaplicy Kościeleckich w Kościelcu i pałac w Brodnicy.

\subsection{Schyłek epoki nowożytnej (od najazdu szwedzkiego lat} 1655-1657 do rozbiorów) - to upadek miast Rzeczypospolitej, w oczywisty sposób niesprzyjajacy kształtowaniu okazałych ratuszy. Dominowały wzory tradycyjne, jak w znanym z pomiaru z 1795 r. ratuszu starosądeckim, o planie przyziemia powtarzającym tradycyjny układ kramów ${ }^{71}$. Do wyjątków należały niektóre miasta prywatne, m.in. wielkopolskie Leszno, w którym do serii fundacji Leszczyńskich, realizowanych przez wykształconego w Rzymie wysokiej klasy włoskiego architekta Pompeo Ferrariego, należy późnobarokowy ratusz, na nowo ukształtowany po pożarze z 1712 r., z wysoka wieża akcentującą fasadę ${ }^{72}$. Na Rusi wyróżnia się rokokowy ratusz w Buczaczu, wzniesiony w połowie XVIII w. staraniem właścicieli miasta - Potockich - przez wybitnego lwowskiego architekta Bernarda Meretyna, z bogatym wystrojem architektoniczno-rzeźbiarskim, zdominowany przez potężna wieżę ${ }^{73}$.

${ }^{69}$ E. Gassiorowski, Rynek $i$ ratusz..., s. 20-27; T. Chrzanowski, M. Kornecki, Chetmno..., s. 58 .

${ }^{70}$ M.G. Zieliński, Chetmno, civitas totus Prussie metropolis XVI-XVIII w., Bydgoszcz 2007, s. 258 - sugeruje autorstwo odnotowanych w aktach parafialnych budowniczych włoskich, Gaspera i Jakuba.

${ }^{71}$ B. Krasnowolski, Lokacyjne układy urbanistyczne na obszarze Ziemi Krakowskiej $w$ XIII i XIV wieku, cz. 2, Kraków 2004, s. 229.

${ }^{72}$ W. Dalbor, Pompeo Ferrari 1660-1736. Działalność architektoniczna $w$ Polsce, Warszawa 1938.

${ }^{73}$ Z. Hornung, Bernard Merettini i jego główne dzieła - kościót pomisjonarski $w$ Horodence, ratusz w Buczaczu i katedra św. Jura we Lwowie, „Prace Komisji Historii Sztuki” 5, 1933-1934. 
Wspomniane realizacje należały do wyjątków. Pewne ożywienie przyniosła epoka oświecenia z seria ,idealnie” rozplanowanych małych miast (raczej miasteczek) prywatnych ${ }^{74}$, aczkolwiek najciekawsze realizacje przypadły już na epokę rozbiorów. Zjawisko to zapowiadał małopolski Frampol Marka Antoniego Butlera z około 1717 r., gdzie ratusz akcentuje środek kwadratowego rynku, wpisanego $\mathrm{w}$ nawiąaniu do idealnych miast późnego renesansu w kwadratowy obwód miasteczka. W wielkopolskim Rostarzewie, założonym w 1752 r., ratusz o prowincjonalnych formach, kubicznej bryle, piętrowy, nakryty wysokim łamanym dachem, zaakcentował centrum prostokątnego rynku i zarazem oś wytyczoną przez główną ulicę.

Znacznie ambitniejszy program realizował w Białymstoku Jan Klemens Branicki ${ }^{75}$. Na ulicowym placu - Rynku Starego Miasta (Nowe Miasto zostało sprzężone z pałacem) - w latach 1745-1761 stanął późnobarokowy ratusz. Nad ta budowla parterowa, ale nakrytą wysokim łamanym dachem, z czterema alkierzami na narożnikach kojarzacymi się z pałacem lub co najmniej dworem, dominowała wysoka wieża akcent urbanistyczny miasta - której forma, przejście w rzucie z kwadratu do ośmioboku, zapewne celowo nawiązywała do wczesnych tradycji wież ratuszowych.

Jeśli w Białymstoku mamy do czynienia z „wpisaniem” ratusza w starszą strukture przestrzenna miasteczka, to Siedlce kanclerza Michała Czartoryskiego i jego córki Aleksandry Ogińskiej sa przykładem nowej, osiowej kompozycji urbanistycznej z około połowy XVIII w., zaakcentowanej w pierzei rynkowej przez nieco wcześniejszy kościół parafialny, zaś pośrodku wydłużonego rynku przez wczesnoklasycystyczny ratusz z przełomu 60. i 70. lat XVIII stulecia, jedno z pierwszych dzieł wybitnego architekta doby stanisławowskiej Stanisława Zawadzkiego.

Równie ambitne są realizacje Anny z Sapiehów Jabłonowskiej z 70. lat XVIII w.: podlaskie Siemiatycze (układ urbanistyczny nawiąujący do Nancy Stanisława Leszczyńskiego) i małopolski Kock. Ratusze - w Siemiatyczach czteroskrzydłowy (z programem obejmującym też kramy), wypełniający wnętrze rynku, w Kocku zamykający rynkową pierzeję uzyskały podobne formy symetrycznie komponowanej, wczesnoklasycystycznej architektury, z dominantami w postaci wysokich wież (przypominające wspomniane rozwiązanie w Siedlcach). Czteroskrzydłowy

\footnotetext{
${ }^{74}$ Zob. przypis 8 .

${ }^{75}$ J. Glinka, Plan Białegostoku z końca XVIII stulecia, w: Studia z historii budowy..., s. $221-222$.
} 
ratusz we wnętrzu rynku, obejmujący też zespoły kramów, otrzymały Postawy na Białorusi, miasteczko ukształtowane urbanistycznie dzięki Antoniemu Tyzenhauzowi około 1791 r. Osiową kompozycję z silnie wydłużonym rynkiem, akcentowaną przez pałac właściciela i ratusz, prezentuja Kozienice, odbudowane w 1782 r. staraniem królewskiego bratanka, Stanisława Poniatowskiego.

Typowym zjawiskiem była jednak nie budowa nowych ratuszy i nawet nie przebudowa dawnych, lecz postępujacca - wraz z cała zabudowa miejska - ruina tych ostatnich. Wymownym i typowym przykładem są losy ratusza w podkrakowskim Kazimierzu, który próbowano remontować... nierealizowanymi decyzjami rady miejskiej. I tak np. w 1689 r. uchwalono odrestaurowanie i nakrycie wieży, 2 lata później postanowiono sprzedać zdjęte $\mathrm{z}$ wieży ołowiane pokrycie i „zebranymi stąd pieniędzmi wiązanie drewniane zreperować", po kolejnych 2 latach, gdy pieniądze roztrwoniono czy raczej rozkradziono, postanowiono „nakryć wieżę ratuszowa, która odarta” - groziła zawaleniem. Kolejne postanowienia - z 1703 r. - dotyczyły likwidacji niektórych elementów ratusza i przyległych doń sukiennic: chciano „Zwalić dach zepsuty nad sienią pomiędzy sklepami sukiennic oraz rozrzucić pawiment przez izbę sądową i ławniczą i zrobić tylko ganek, czyli chodzenie do izby ławniczej i do sklepów sukiennic”. Po kilkudziesięciu latach, w 1784 r., rada miejska postanowiła, aby „podać suplikę do króla o określenie jakiego funduszu ze Skarbu Koronnego na remont ratusza kazimierskiego"76. Rozważano możliwość ratowania budynku przez powiązanie go z rujnującą miasta Rzeczypospolitej plagą kwaterunków wojskowych; w 1787 r. działającej wówczas w Kazimierzu królewskiej Komisji Dobrego Porządku został przedłożony przez władze miejskie projekt przebudowy ratusza, do którego dodano by pomieszczenia dla wojska - Komisja zaakceptowała pomysł, „widząc, że podany projekt jest nie ku ozdobie przez reformę ratusza miasta, ale i ulga obywatelów w unkwaterunku" "77. Na realizację zamierzenia zabrakło zarówno czasu, jak pieniędzy. Typowy obraz dla tej smutnej epoki upadku Rzeczypospolitej daje akwarela Zygmunta Vogla z 1792 r., przedstawiająca ruinę średniowiecznego ratusza w Olkuszu, stercząca pośród ruin zabudowy miejskiej ${ }^{78}$.

${ }^{76}$ BJ, Teki Żegoty Paulego, sygn. 5357/II, t. 7, k. 108v-109v, 112.

${ }^{77}$ Archiwum Narodowe w Krakowie, Akta miasta Kazimierza, akta Komisji Dobrego Porządku, sygn. K-839, s. 69.

${ }^{78}$ Gabinet Rycin Biblioteki Uniwersytetu Warszawskiego; widok publikuje m.in.

W. Komorowski, Średniowieczne ratusze..., s. 246. 
3. Wystrój i jego symbolika ewoluowały wraz z przekształceniami architektonicznymi.

3.1. Wystrój najwcześniejszych ratuszy jest niemal nieznany. Do najstarszych zachowanych elementów należy zwornik sklepienny z pierwszych lat XIV w., znajdujący się w piwnicy poznańskiego ratusza, z czeskim Lwem, poświęcony zatem monarsze - Wacławowi II Czeskiemu, a więc należący do wątku tak popularnego w znacznie lepiej znanych późniejszych wystrojach gloryfikującego feudalnych panów miasta. W bogatych miastach śląskich i pomorskich - owe najwcześniejsze wystroje bez wattpienia przepadły w wyniku późniejszych gruntownych przekształceń. Do istniejacych do dziś elementów należy wschodni portal wrocławskiego ratusza z około połowy XIV w. z czeskim Lwem między herbami Ślaska i Wrocławia w tympanonie. W znacznie skromniejszej, niemal bezstylowej najstarszej architekturze miejskiej Małopolski - wystrój plastyczny mógł się w ogóle nie pojawić lub być wielce ograniczony.

3.2. W dobie schyłkowego gotyku w szczególnie bogatych formach ukształtowano rzeźbiarski i malarski wystrój ratusza wrocławskiego, związany z jego wspomnianą rozbudową i przebudową z lat 1470-1510 ${ }^{79}$. Symbolika tego niezupełnie jednolitego zespołu jest zapewne bardziej skomplikowana, niż wynikałoby to z dotychczasowych interpretacji badawczych. Wydaje się, że w dekoracji elewacji zastosowano układ „strefowy”, odpowiadający dyspozycji funkcjonalnej ratusza ${ }^{80}$. Dolna strefa, komentująca funkcje ogólnodostępnych piwnic (m.in. wyszynk piwa i wina), dekorowana jest płaskorzeźbami i rzeźbami o charakterze rodzajowym, utrzymanymi w duchu nieco późniejszej literatury sowizdrzalskiej. W strefie górnej widzimy rycerzy, a więc przedstawicieli warstwy społecznej, do której pretendowały mieszczańskie elity; umieszczone tu przedstawienia można też traktować jako alegorie Pokoju który zapewniają władze miejskie - i Wojny, przed którą chronia.

Dekoracja heraldyczna wnętrz (skoncentrowana zwłaszcza na zwornikach tzw. Refektarza) wymaga starannych badań. Jej ważnym

${ }^{79}$ M. Zlat, Rzeźbiarska i malarska dekoracja ratusza we Wrocławiu, w: M. Bukowski, M. Zlat, Ratusz wroctawski..., s. 195-244; M. Kapustka, Natura czy geometria w późnogotyckiej dekoracji Ratusza Wrocławskiego - konflikt czy zależność, w: Wrocławski Rynek..., s. 19-28; P. Oszczanowski, Reprezentatywność wtadzy, czyli sztuka na ustugach Rady Miejskiej we Wroctawiu, w: Rada Miejska Wrocławia przez wieki. Materiaty z Konferencji, Wrocław 17 czerwca 2008, red. W. Dryll, Wrocław 2008, s. $23-40$.

${ }^{80}$ J. Trzynadlowski, dz. cyt., s. 5; interpretacja przekazu: Barttomieja Steina renesansowe opisanie Wroctawia, wyd. R. Żerlik, Wrocław 1995. 
(przewodnim?) elementem jest często powtarzająca się w średniowiecznych i nowożytnych wystrojach ratuszy wierność panu feudalnemu, a więc w tym wypadku królowi Czech, co wyraża dekoracja tympanonu w portalu wiodaccym do Sali Książęcej, gdzie czeski Lew po raz kolejny umieszczony został między herbami Ślaska i Wrocławia. Te same idee przyświecały rzeźbiarskim dekoracjom wież ratuszowych w Świdnicy (niezachowana) i Jaworze (zachowana) z 2. połowy XIV w., a raczej ich ośmiobocznym nadbudowom, gdzie umieszczono posagi królów czeskich, przy czym w pierwszym wypadku towarzyszyły im także wizerunki książąt ślaskich. Jak świadczy przykład Jawora - w parze z czeskim wzorcem ikonograficznym szły też cechy warsztatowe: tutejsze posagi władców wiązane są $\mathrm{z}$ warsztatem praskiego mistrza Piotra Parlera ${ }^{81}$.

Ułamkowa jest nasza wiedza o późnogotyckich malarskich dekoracjach ratuszy. Mogły one wypełniać blendy rozczłonkowujące elewacje, skoro w Środzie Śląskiej w jednej z takich blend ukazano „iluzjonistycznie" okno, a w nim przedstawiciela księcia odbierającego ślubowanie mieszczan $^{82}$. Jest to zatem kolejna - obok zestawów herbów i posagów - wersja wystroju akcentującego lojalność miasta wobec pana feudalnego. Nie wiemy, czy było to wyobrażenie wyjątkowe, czy reprezentujące szerzej stosowana konwencję. Badania elewacji ratusza w Brzegu ujawniły resztki późnogotyckich dekoracji z imitacjami okien, które zdaniem Rafała Czernera symbolizowałyby „otwarty charakter władzy"83. Iluzjonizm znajdował też odzwierciedlenie w gotycko-renesansowych wystrojach wnętrz; w Izbie Rady ratusza wrocławskiego w 1548 r. pojawiło się malowidło imitujące półkę z ustawionymi na niej przedmiotami. W dolnych partiach ścian dekoracja ta - zgodnie z powszechna konwencja - naśladowała dywany ${ }^{84}$.

Interesujace światło na wystroje reprezentacyjnych sal rzucaja późnogotyckie malowidła ścienne ujawnione w ratuszu w Świdnicy, datowane na 30. lata XVI w., wykonane po pożarze z 1528 r. Tematyka (Sąd Ostateczny, Sąd nad jawnogrzesznica) wiąże się z funkcją sądowniczą ${ }^{85}$. Wydaje się, że temat Sądu Ostatecznego mógł pojawiać się w ratuszowych wnętrzach znacznie wcześniej, skoro zalecało go już Zwierciadto Saskie.

${ }^{81}$ R. Czerner, C. Lasota, Blok ratuszowy..., s. 88-90.

${ }^{82}$ R. Czerner, J. Kościuk, dz. cyt., przypis 21.

${ }^{83}$ R. Czerner, Ratusz w Brzegu..., s. 89.

${ }^{84}$ J. Trzynadlowski, Zaginiony wystrój Izby Rady ratusza wrocławskiego, w: Wroctawski Rynek..., s. 39.

${ }^{85}$ R. Czerner, C. Lasota, Blok ratuszowy..., s. 102, 105. 
W podobnym okresie powstały malowidła reprezentacyjnej sali ratusza we Lwówku ${ }^{86}$, z alegorycznymi przedstawieniami Sprawiedliwości i Miłosierdzia, wiążącymi się z funkcją sądowa.

\subsection{W początkach ery nowożytnej (połowa XVI - początek} XVII w.) na czoło wysuwaja się wystroje poznańskiego ratusza, kolejne modyfikacje wystrojów ślaskich ratuszy, a nade wszystko bogato kształtowane wyposażenia ratuszy z terenów Prus Królewskich, w tym zwłaszcza Gdańska i Torunia. Sa to wielce uczone wywody, często wyrażane językiem emblematów, z licznymi nawiązaniami do tekstów biblijnych, mitologii oraz historii starożytnej: Grecji, Izraela, Rzymu, wymagające od odbiorców - patrycjuszy o uniwersyteckich studiach znacznej erudycji, a nade wszystko zdolności myślenia za pomoca alegorii i symboli. Na tym tle nader skromnie przedstawia się Małopolska, a nawet sam Kraków, co było niewątpliwie odzwierciedleniem rysującego się już wówczas wyraźnie regresu miast Królestwa Polskiego.

Omówioną architekturę poznańskiego ratusza - pałacu miejskiego - komentuje współczesna jej (i nieco późniejsza) dekoracja plastyczna, charakteryzowana przez Jana Skuratowicza ${ }^{87}$. W attyce (nawiąującej do corona muralis), wieńczącej fasadę, znalazły się wizerunki Jagiellonów, uzupełniane potem przedstawieniami kolejnych elekcyjnych królów, którymi zastępowano starsze sceny o nieznanym dzisiaj temacie. Dwunawowy podział Wielkiej Sieni - to odwołanie się do wspomnianej wcześniej tradycji średniowiecznej, a zarazem może nawiązanie do dwunawowych hal cesarskich. W serliańskie geometryczne ramy wpisane zostały figuralne reliefy, tworzace skomplikowane rebusy, z kosmologiczna symbolika, stanowiące popis renesansowej erudycji. W nawie południowej alegorie siedmiu planet (towarzyszą im znaki Zodiaku) symbolizują tu m.in. życie ludzkie, którego kres wyznaczać może piekło (gryf), ale - jeśli jest ono normowane przez reprezentowane w tej sądowej sali prawo boże (wyrażają je Mojżesz - prawodawca i Jezus Chrystus) - prowadzi do nieba (orzeł). Wspomniana symbolika jest wieloznaczna, bo niektóre planety - to także symbole czterech żywiołów, a Jowisz jest ponadto, jak Mojżesz, prawodawca. Twórca tego programu mógł być ówczesny burmistrz Kasper Goski ${ }^{88}$, absolwent krakowskiej Akademii, astrolog, lekarz i matematyk, którego podobizna towarzyszy być może przedstawieniu gryfa. Analogicznie skomponowany program zawarty w nawie północnej wyraża - w podobnym, alegoryczno-emble-

\footnotetext{
${ }^{86}$ J. Eysymontt, dz. cyt., s. 6.

${ }^{87}$ J. Skuratowicz, dz. cyt., s. 22-23.

${ }^{88}$ H. Barycz, Kasper Goski, PSB 8, 1959-1960.
} 
matycznym, uczonym języku - współzależności pomiędzy państwem (reprezentowanym przez herby Polski i Litwy oraz symbole odnoszące się zarówno do zmarłego króla Zygmunta Starego i Bony, jak do panującego wówczas Zygmunta Augusta z Elżbieta Rakuszanka) a miastem (herb Poznania). Pomiędzy herbami widzimy postacie ze starożytnych legend (Marek Kurcjusz) i mitologii (Herakles) oraz Starego Testamentu (Dawid z Goliatem, Samson), mówiące o walce, bohaterstwie, poświęceniu, obywatelskich cnotach; te same treści - lecz zgodnie z chrześcijańska ikonografia, znaną od średniowiecza - wyraża pelikan karmiący pisklęta własną krwią.

Wśród miast Królestwa Polskiego doby nowożytnej odrębna pozycję zajmował Gdańsk, o ludności stale wzrastającej, stale bogacącej się, pragnącej sztuki wysokich lotów, sztuki wyrażającej coraz większe ambicje polityczne. Nowożytny Gdańsk to w całym tego słowa znaczeniu miasto zachodnioeuropejskie, odporne wobec wyraźnie rysującego się kryzysu miast polskich. To także - jak podkreśla Teresa Grzybkowska - miasto zróżnicowane społecznie, o ogromnym dystansie dzielacym elitę patrycjatu od ogółu mieszczaństwa, dystansie bezprecedensowym nie tylko w skali ziem polskich, lecz nawet $\mathrm{w}$ porównaniu z nie mniej przecież ambitnym Toruniem ${ }^{89}$.

W sztuce szczególnym odzwierciedleniem ambicji gdańskiej elity stał się wystrój reprezentacyjnego wnętrza ratusza Głównego Miasta - Sali Czerwonej - kształtowany w dwóch etapach z udziałem wybitnych niderlandzkich artystów, Hansa Vredemana de Vries (czynnego tu w latach 1592-1595) i Izaaka van den Blocke (1604-1608) ${ }^{90}$, z charakterystycznym dla niderlandzkiego manieryzmu zjawiskiem horror vacui, wynikającym zarówno $\mathrm{z}$ perfekcji $\mathrm{w}$ drobiazgowym opracowywaniu delikatnych form, jak z obfitości symbolicznych treści. Obowiązuje strefowość kompozycji. W dolnych partiach ścian widzimy ławy i boazerie z dekoracyjnymi, geometrycznymi intarsjami, których formy mówią o świecie nieożywionym, a pojęciu temu (siłom natury) odpowiada toskański porządek portalu i kominka. Wyżej - również w intarsjach - mamy świat roślin i zwierząt. W kolejnej sferze, wypełnionej przez siedem ogromnych, malowanych na płótnie obrazów Vredemana de Vries, dochodzimy do świata ludzi. Zwieńczenie - fryz pod stropem z przedstawieniami znaków Zodiaku i planet - to Kosmos. Tę dekorację, należąca do pierwszego etapu kształtowania wnętrza, uzupełniały plafonowe dekoracje autorstwa Hansa Vredemana, eksponujące herby

\footnotetext{
${ }^{89}$ T. Grzybkowska, dz. cyt., s. 19-21.

${ }^{90}$ Tamże, s. 31-39; T. Zarębska, Przebudowa Gdańska..., s. 74-75.
} 
Polski, Litwy, Prus Królewskich i Gdańska. Były odpowiednikami tych samych motywów wypełniajacych okna (jako witraże, o typowym dla Niderlandów charakterze), a także wcześniejszej (1561 r.) złoconej statui Zygmunta Augusta, wieńczącej hełm wieży. Zdaniem Teresy Zarębskiej, trzymana przez króla włócznia, widoczna z daleka, mogła być świadomym nawiazzaniem do ateńskiej Akropolis, z fidiaszowym posagiem dzierżącej włócznię Ateny Promachos.

Te zewnętrzne wyrazy czci oddawanej Królestwu Polskiemu, niezupełnie zgodne z polityka gdańskiej Rady (mieniącej się już wówczas Senatem), były - jak się wydaje - drażniące dla gdańskich elit, dążących praktycznie do pełnej suwerenności miasta przy zachowaniu pozorów lojalności wobec Polski. Zdaniem Eugeniusza Iwanoyki ${ }^{91}$ (polemizującego tu z Władysławem Tomkiewiczem i Halina Sikorską ${ }^{92}$ ) oraz Teresy Zarębskiej ${ }^{93}$, było to przyczyną usunięcia plafonów autorstwa Hansa Vredemana i zastapienia ich nowymi, wykonanymi przez Izaaka van den Blockego. Erudycyjny popis, wymagający od odbiorców głębokiej wiedzy z zakresu mitologii i historii starożytnej Grecji i Rzymu, Biblii, tak charakterystycznych dla epoki traktatów emblematycznych Andrei Alcatiusa i Cesare Ripy, a przy tym interpretacji dokonywanych przez humanistów włoskich (Marsilio Ficino) i niderlandzkich (Erazm z Rotterdamu) - tworzy trudne do prawidłowego odczytania rebusy i układy obfite w zawiłe skojarzenia. Całość wyraża wierność miastu Gdańsk i jego władzom, a w zasadzie ambicje miasta do bytu w pełni suwerennego. Spowodowałoby to konflikt z Królestwem Polskim, gdyby... treść, w której pojawiają się przecież czytelne odwołania do Polski i Litwy, była zrozumiała poza waskim gronem wtajemniczonych, elitą gdańskiego patrycjatu, mówiąc dzisiejszym językiem: „grupa trzymajaca władzę”. Ale nie była nawet dla większości gdańszczan, w tym dla autora opisu sporządzonego w końcu XVII w. ${ }^{94}$, a więc zaledwie 90 lat później od powstania samego dzieła.

Nieco później (1617 r.) Abraham van dem Blocke stworzył wystrój reprezentacyjnej sali gdańskiego Dworu Artusa, wplatając w treść wczesnośredniowiecznej legendy o królu Arturze wielkich zwycięzców ze starożytności: Temistoklesa, Scypiona Afrykańskiego, Judę Machabeusza, gloryfikujący też - acz marginalnie, bo w formie niewielkich medalionów - polskich władców: Zygmunta III Wazę i jego następcę, królewicza Władysława.

\footnotetext{
${ }^{91}$ E. Iwanoyko, Apoteoza...; tenże, Interpretacje..., s. 9-24; tenże, Gdański okres...

${ }^{92}$ W. Tomkiewicz, dz. cyt.; H. Sikorska, dz. cyt.

${ }^{93}$ T. Zarębska, Przebudowa Gdańska, s. 74-75.

${ }^{94}$ T. Domagała, Wnętrza..., s. 25-47.
} 
W podobnym okresie, z wyraźnym nawiązaniem do gdańskiej Sali Czerwonej, ukształtowano wystrój reprezentacyjnych wnętrz ratusza w Toruniu, z obrazami gdańszczanina Antoniego Möllera. Oprócz portretów królów polskich na szczególną uwagę zasługuje rozwiązanie plafonowego stropu, podzielonego na dwanaście pól, wypełnionych obrazami sławiącymi szczęśliwość miasta związanego z Rzeczapospolita; nawiązanie do rzymskiego Lex duodecim tabularum (motyw ten występuje też w gdańskiej Sali Czerwonej) - to popis erudycji torunskich mieszczan, a zwłaszcza burmistrza z lat 1587-1609, Henryka Strobanda, prawnika, filozofa i protestanckiego teologa, absolwenta uniwersytetów we Frankfurcie, Tybindze i Wittenberdze ${ }^{95}$.

$\mathrm{Na}$ szczególną uwagę zasługuje rzeźbiarski wystrój niezachowanej fasady ratusza w Elblagu z 50. lat XVI w. ${ }^{96}$ Oprócz „strefowej” kompozycji z personifikacjami planet - strefy niebieskiej - w zwieńczeniu, natrafiamy tu na wczesny przykład zainteresowania historia, której lokalny wymiar (m.in. płaskorzeźba odnosząca się do walk z Prusami) jest gloryfikowany poprzez odniesienia do bohaterów wojny trojańskiej.

Niderlandzka sztuka Pomorza oddziaływała na Ślask. Przykładem był niezachowany dzisiaj wystrój Izby Rady we wrocławskim ratuszu, ukształtowany w latach 1563-1564, z intarsjowanymi boazeriami (motywy geometryczne) i drzwiami prowadzacymi do Sali Sąowej, na których znalazły się przedstawienia mówiące o tejże funkcji, m.in. alegorie Wiary i Sprawiedliwości ${ }^{97}$.

Bez porównania skromniej przedstawiały się wystroje ratuszy małopolskich: brakowało tu zarówno przestrzeni do rozwinięcia skomplikowanych wątków treściowych, jak i dostatecznie zamożnych i wykształconych odbiorców (mecenat mieszczański miał tu wszak swój najlepszy okres już za soba), a także wybitnych artystów, którzy pracowali głównie na usługach króla, magnaterii i Kościoła. Z fragmentarycznie zachowanych dzieł i przekazów wynika, że popularnym, zapewne obowiązkowym tematem dekoracji plastycznej ratuszy była gloryfikacja feudalnego właściciela miasta. Ciekawym przyczynkiem do badań nad ówczesnym wystrojem i jego symbolika jest siedemnastowieczny dokument cytowany przez Władysława Bogatyńskiego o dekoracji malarskiej attyki ratusza w Tarnowie, gdzie umieszczono wizerunki kolejnych

${ }^{95}$ J. Małłek, Henryk Stroband (1548-1609), reformator i wspóttwórca Gimnazjum Akademickiego $w$ Toruniu, „Echa Przeszłości” 11, 2010, s. 63-68; Henryk Stroband (1548-1609) - burmistrz toruński: $w$ czterechsetna rocznicę śmierci, red. K. Mikulski, Toruń 2010.

${ }^{96}$ W. Rynkiewicz-Domino, Budownictwo..., s. 239.

${ }^{97}$ J. Trzynadlowski, Zaginiony wystrój..., s. 41. 
właścicieli miasta ${ }^{98}$. Zachodzi tu nieprzypadkowa zbieżność pomiędzy liczbą kolejnych właścicieli, od Spicymira Leliwity po Jana Krzysztofa Tarnowskiego, a ilościa blend $\mathrm{w}$ attyce $(28)^{99}$. To niemal pewne, że $\mathrm{w}$ blendach renesansowych attyk małopolskich ratuszy stojących na rynkach miast królewskich umieszczone były wizerunki polskich królów; należałoby ich się domyślać np. w Sandomierzu i podkrakowskim Kazimierzu, gdzie attyka otrzymała zwieńczenie krenelażowe. Motyw ten, powtarzajacy się też w innych krakowskich budowlach z 2. połowy XVI stulecia, należy tu interpretować jako świadome, symboliczne nawiązanie do średniowiecznej warowni, do corona muralis, a więc elementu charakteryzującego wiele miejskich herbów.

Królewskie portrety zdobiły też zapewne reprezentacyjne wnętrza ratuszowe Małopolski. Znajduje to potwierdzenie w wystroju Izby Pańskiej krakowskiego ratusza, znanego z litografii wykonanej według rysunku Józefa Brodowskiego sprzed 1820 r.: podstropowy fryz tworzyły tu medaliony z portretami królów, dzieło krakowskiego malarza Kaspra Kurcza z 1593 r. ${ }^{100}$ Jednocześnie wnętrze to można uznać za wyraz tęsknoty krakowskich rajców za bogactwem i przepychem towarzyszącym gdańskiemu Senatowi: bogato zdobione, intarsjowane drzwi (dzieło snycerza-artysty Piotra Kaliny z tegoż 1593 r., dzisiaj zachowane, wraz z portalem, w uniwersyteckim Collegium Maius) ${ }^{101}$, to jakby skromne nawiązanie do wspomnianych intarsjowanych dekoracji Sali Czerwonej gdańskiego ratusza Głównego Miasta. Być może stamtąd (ale niewykluczone, że z królewskiego Wawelu lub magnackich pałaców) zaczerpnięto kompozycję plafonowego stropu.

Eksponowanie Orła polskiego było zapewne równie częstym elementem dekoracji małopolskich ratuszy jak cykle królewskich portretów. Z gloryfikacją godła państwowego spotykamy się w renesansowym ratuszu Biecza ${ }^{102}$. Zapewne dekoracja ratusza w Żywcu inspirowany był wiersz, który w swym Dziejopisie z około 1704 r. zamieścił wójt Andrzej Komaniecki: „Bądźże żubrze podległy białemu orłowi” ${ }^{103}$. Notabene

${ }^{98}$ W. Bogatyński, Hetman Jan Tarnowski 1488-1561, Kraków 1913, s. 180-181.

${ }^{99}$ B. Krasnowolski, Ekspozycja muzealna jako interpretacja historycznych $i$ artystycznych wartości ratusza w Tarnowie, „Arkusze Muzealne Ziemi Krakowskiej” 1975.

${ }^{100}$ A. Fischinger, Kasper Kurcz, renesansowy malarz krakowski, „Studia Renesansowe" 2, 1957, s. 218-240.

${ }^{101} \mathrm{~K}$. Sinkówna, Portal i drzwi z dawnego ratusza krakowskiego $i$ ich domniemany twórca, „Prace Komisji Historii Sztuki” 6, 1934-1935, s. 31-37.

${ }^{102}$ S. Walczy, S. Załuski, dz. cyt., s. 183.

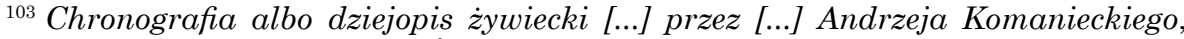
wyd. S. Grodziski, I. Dwornicka, Żywiec 1987. 
autor zapewne nie wiedział już, że Orzeł umieszczony w herbie Żywca ponad głowa żubra jest herbem Ślaska, a nie godłem Polski.

Bogaty program prezentował wystrój ratusza lwowskiego, z licznymi łacińskimi sentencjami (zanotowanymi przez Szymona Starowolskiego ${ }^{104}$ ), sławiącymi sprawiedliwe rządy i mieszczańskie cnoty. Salę rady ${ }^{105}$ oprócz portretów królewskich zdobiły też wizerunki hetmanów, a także papieża Sykstusa V, co zdaje się wskazywać na jeden z etapów kształtowania wystroju (1585-1590). Zapewne w kontekście uniwersalnego Kościoła i boskiej sprawiedliwości należy tu widzieć mapy Europy, Azji i Afryki oraz przedstawienie Sądu Ostatecznego.

Konkluzja. Architektura i wystrój ratuszy - to rodzaj syntezy ambicji i kondycji stanu mieszczańskiego w różnych okresach dziejowych. Różnorodna problematyka, która - w wyborze, w oparciu o całokształt badań - starano się tu zaprezentować, jest odzwierciedleniem procesów historycznych, przebiegających często podobnie, lecz równie często odmiennie w poszczególnych regionach. Ważnym kierunkiem badań może być wędrówka i postępująca wraz z nią ewolucja idei odzwierciedlanych $\mathrm{w}$ architekturze i sztuce - od wielkich ośrodków Zachodu, poprzez najświetniejsze miasta polskie, do prowincjonalnych miasteczek.

\section{Bibliografia}

Balińska G., Rozwój urzqdzeń handlowych $i$ administracyjnych $w$ blokach śródrynkowych miast ślaskich do końca XV w., „Kwartalnik Architektury i Urbanistyki" 26, 1981, s. 127-156.

Bukowski M., Zlat M., Ratusz wrocławski, Wrocław 1958.

Czerner R., Zabudowy rynków. Średniowieczne bloki śródrynkowe wybranych dużych miast Ślaska, Wrocław 2002.

Gassiorowski E., Ratusz staromiejski w Toruniu, Torun 2004.

Gasiorowski E., Rynek i ratusz chetmiński, „Kwartalnik Architektury i Urbanistyki” 10, 1965, z. 1, s. 3-28.

Grzybkowska T., Między sztukq a polityka. Sala Czerwona Ratusza Głównego Miasta w Gdańsku, Warszawa 2003.

Komorowski W., Średniowieczne ratusze w Matopolsce i na ziemiach ruskich Korony, w: Civitas et villa. Miasto i wieś w średniowiecznej Europie środkowej, red. C. Buśko, Wrocław 2002, s. 241-248.

${ }^{104}$ S. Starowolski, Monumenta Sarmatarum, viam universae carnis ingressorum, Cracoviae 1655.

${ }^{105}$ F. Jaworski, dz. cyt., s. 44-46. 
Ratusz w miastach pótnocnej Europy. Materiaty z sesji „Ratusz w miastach nadbattyckich”, Gdańsk 23-25 XI 1993, red. S. Latour, Gdańsk 1997. Szczepański J., Ratusze polskiego pobrzeża Battyku, Gdańsk 1996.

\section{Bogusław Krasnowolski}

The construction and reconstruction of town halls in the cities of the Kingdom of Poland until the end of the 18th century

\section{(Summary)}

The article, which also takes into account the issues relating to the medieval town halls in Silesia, Western Pomerania and the Teutonic State, is an attempt at synthesizing the existing research. The following aspects have been analysed: the location of the town hall within the urban complex and the transformation of the forms and symbols of both its architecture and design.

Town halls came into existence as a consequence of - although not necessarily immediately - founding towns based on German Law and the establishment of municipal authorities. The relationship between the town halls and urban planning varied. The town hall could be located along the front of the main market square (Wieliczka in Małopolska) or a street - a place functioning as the market square (evolution of the urban context in the town hall in Gdańsk), sometimes (due to the location of the house of the municipal councillor?) outside the market place (originally in Nowy Sacz). Its location along the front of the market square in Early Modern towns could have both an aesthetic and symbolic aspect (Zamość). The evolution of the central-market square block, with the town hall and stalls was very characteristic of medieval towns and influenced the Małopolska region (Kraków) and Wielkopolska region (Poznań) from Silesia (Wrocław, Świdnica, Legnica). In Early Modern private towns, from the Renaissance era (Głowów) to the late Baroque (Siedlce), the town hall was often situated in a place which emphasized the axes of the urban layout.

The tower was usually an important element in the architecture of the oldest town hall buildings (13th/14th century). It emphasized the town's autonomy and, similarly to the adjacent hall, was derived from the architecture of feudal castles (Wrocław, Kraków). The tower also emerged as the oldest element of the central-market square block in many Silesian towns, and was modelled on the beffrois (Bruges). The form of a tower came to the Małopolska region in the 14th century (the oldest town hall in Sandomierz) and Ruthenia (Krosno, Kamieniec Podolski). Two-naved halls which alluded to the palatium (Poznań), were particularly frequent in Western Pomerania (Stargard, Pasłęk, Kamień Pomorski, Chojnice, Szczecin). By contrast to the simple, purely functional architectural forms of the oldest town halls, in the lands of the Teutonic knights fine details were present as early as in the early 14th century (Chełmno). The richness of the forms and designs of the Pomeranian town 
halls, with Torun at the forefront (which Jan Długosz noticed) had an impact on the late Gothic town halls in the Małopolska region (reconstruction of the Kraków town hall, 1454). The transfer of the official functions from the ground floor of the town hall to the Artus Court could also relate to Kraków. Bohemian models played a large role in the shaping of representative architecture, symbolism and the iconographic programme of the late Gothic town halls in Silesia (15th/16th century) - e.g. the relationship between the Ladislaus Room in Hradčany and the Lwówek town hall.

In Early Modern times the "bipolarity" of architectural designs in Polish lands, which were inspired by ideas coming both from Italy and the Netherlands is most noticeable on examples in the Małopolska region, notably Kraków (attics surmounting the buildings) and Pomerania, notably Gdańsk, where the designs by masters from the Netherlands were subordinated to erudite, complicated political "treaties". In the Wielkopolska region the Mannerist style inspired by Northern Italian (Serlian) designs was at the forefront as can be seen in the reconstruction of Poznań's town hall.

In the era of urban decline in the Polish-Lithuanian Commonwealth (2nd half of the $17 \mathrm{th} / 18$ th century) anachronistic, medieval designs continued to be used (Stary Sacz); private towns were an exception (e.g. Leszno and Buchacz owned by the Leszczyński family), which were able to afford magnificent constructions.

The architecture and design of town halls reflect the ambitions as well as the condition of the bourgeoisie and therefore the phenomena which took various forms in the different historical periods and regions. Future research should put special emphasis on tracing the "migration" of designs and ideas from the magnificent urban centres of the West through the main Polish cities to provincial towns.

Key w ord s: town hall, the central-market square block, municipal council, urban architecture. 